NBER WORKING PAPER SERIES

\title{
THE SOCIAL SECURITY WINDFALL ELIMINATION AND GOVERNMENT PENSION OFFSET PROVISIONS FOR PUBLIC EMPLOYEES IN THE HEALTH AND RETIREMENT STUDY
}

\author{
Alan L. Gustman \\ Thomas L. Steinmeier \\ Nahid Tabatabai \\ Working Paper 19724 \\ http://www.nber.org/papers/w19724 \\ NATIONAL BUREAU OF ECONOMIC RESEARCH \\ 1050 Massachusetts Avenue \\ Cambridge, MA 02138 \\ December 2013
}

This work was supported by a grant from the Social Security Administration through the Michigan Retirement Research Center (UM13-07), with subcontracts to Dartmouth College and to Texas Tech University. The findings and conclusions expressed are solely those of the authors and do not represent the views of the Social Security Administration, any agency of the Federal government, the Michigan Retirement Research Center or the NBER. We would like to thank Robert Clark, Irena Dushi, Howard Iams and Erzo Luttmer for helpful comments, and Mike Nolte for advice on HRS data. The views expressed herein are those of the authors and do not necessarily reflect the views of the National Bureau of Economic Research.

NBER working papers are circulated for discussion and comment purposes. They have not been peerreviewed or been subject to the review by the NBER Board of Directors that accompanies official NBER publications.

(C) 2013 by Alan L. Gustman, Thomas L. Steinmeier, and Nahid Tabatabai. All rights reserved. Short sections of text, not to exceed two paragraphs, may be quoted without explicit permission provided that full credit, including (C) notice, is given to the source. 
The Social Security Windfall Elimination and Government Pension Offset Provisions for Public Employees in the Health and Retirement Study

Alan L. Gustman, Thomas L. Steinmeier, and Nahid Tabatabai

NBER Working Paper No. 19724

December 2013

JEL No. D31,E21,H55,I3,J14,J26,J32,J45

\begin{abstract}
$\underline{\text { ABSTRACT }}$
This paper uses data from the Health and Retirement Study to investigate the effects of Social Security's Windfall Elimination Provision (WEP) and Government Pension Offset (GPO) provision on Social Security benefits received by individuals and households. WEP reduces the benefits of individuals who worked in jobs covered by Social Security and also worked in uncovered jobs where a pension was earned. WEP also reduces spouse benefits. GPO reduces spouse and survivor benefits for persons who worked in uncovered government employment where they also earned a pension.

Unlike previous studies, we take explicit account of pensions earned on jobs not covered by Social Security, a key determinant of the size of WEP and GPO adjustments. Also unlike previous studies, we focus on the household. This allows us to incorporate the full effects of WEP and GPO on spouse and survivor benefits, and to evaluate the effects of WEP and GPO on the assets accumulated by affected families.

Among our findings: About 3.5 percent of households are subject to either WEP or to GPO. The present value of their Social Security benefits is reduced by roughly one fifth. This amounts to five to six percent of the total wealth they accumulate before retirement. Households affected by both WEP and GPO lose about one third of their benefit. Limiting the reduction in the Social Security benefit to half the size of the pension from uncovered employment reduces the penalty from WEP for members of the original HRS cohort by about 60 percent.
\end{abstract}

Alan L. Gustman

Department of Economics

Dartmouth College

Hanover, NH $03755-3514$

and NBER

ALAN.L.GUSTMAN@DARTMOUTH.EDU

Thomas L. Steinmeier

Department of Economics

Texas Tech University

Lubbock, TX 79409

thomas.steinmeier@ttu.edu
Nahid Tabatabai

Department of Economics

Dartmouth College

Hanover, N.H. 03755

Nahid.Tabatabai@dartmouth.edu 
The Windfall Elimination Provision (WEP), enacted in 1983, reduces Social Security payments to entitled beneficiaries who also worked in and earned a pension in uncovered employment. To be affected by WEP, an individual must have been employed in a job covered by Social Security for long enough to qualify for benefits; must have also worked on a job not covered by Social Security, where FICA (Federal Insurance Contributions Act) taxes were not paid; and importantly, must have earned a pension on that uncovered job.

To understand how the Windfall Elimination Provision works, one must have a basic understanding of how Social Security benefits are determined. Benefits are based on a person's highest 35 years of covered earnings. Previous earnings are indexed up to the year the individual turns age 60. Earnings after age 60 are not indexed. The higher are indexed covered earnings, measured by Average Indexed Monthly Earnings (AIME), the higher is the basic benefit a person is entitled to at full retirement age, called the Primary Insurance Amount (PIA). The Social Security benefit formula is designed to be progressive, replacing a decreasing share of earnings as earnings increase. In 2013, the PIA replaced 90 percent of the first \$9,492 of indexed annual earnings; 32 percent of indexed earnings between $\$ 9,492$ and $\$ 57,216$, and 15 percent of indexed earnings over that amount. (To facilitate later analysis, we specify earnings on an annual basis. Social Security formulas are typically specified using monthly amounts.) The actual Social Security benefit paid also depends on when benefits are claimed. If the benefit is claimed before the full retirement age, it is reduced below the PIA. If claimed after the full retirement age, the benefit payment is increased above the PIA.

WEP reduces Social Security benefits by lowering the replacement rate for Average Indexed Monthly Earnings (AIME) up to the first bend point from 90 percent to a minimum of 40 percent. The benefit reduction from WEP is limited to half the value of the pension from uncovered work. So for WEP to have a substantial effect, the pension from uncovered employment must be large relative to the earned Social Security benefit. When a worker's benefits are reduced by WEP, so are associated spouse benefits, but not survivor benefits. ${ }^{1}$

\footnotetext{
${ }^{1}$ For further discussion of WEP, see Social Security Administration (2012a). Brown and Weisbenner (2013) carefully and thoroughly analyze the incentives created by the WEP formula itself. They do not, however, examine the implications of limiting the WEP adjustment to half the value of the pension from uncovered employment.
} 
Congress enacted WEP to eliminate what they perceived to be an unintended windfall (GAO, 2007, p. 6). Before WEP, because Social Security benefits are based on a progressive formula designed to replace a higher fraction of earnings for those with low lifetime earnings, years spent in employment on an uncovered job were treated as years of zero earnings. As a result, some individuals who received relatively high annual earnings throughout their lifetime, in some years from covered employment and in others from uncovered employment, were treated in the calculation of AIME as if they were low earners. ${ }^{2}$

Most, but not all uncovered workers are government employees, although most government employees are covered by Social Security. "According to the Social Security Administration (SSA), as of December 2012, about 1.5 million Social Security beneficiaries were affected by the WEP.”(Congressional Research Service, 2013a, p. 3). ${ }^{4}$

A related program, the Government Pension Offset (GPO), reduces Social Security benefits paid to spouses or survivors when the recipient of the spouse or survivor benefit also earned a pension from working on a government job that was not covered by Social Security. The reduction is equal to two-thirds of the government pension from uncovered work. (Social Security Administration, 2012b). “In December 2011, about 568,000 Social Security beneficiaries (about 1\% of all Social Security beneficiaries) had spousal benefits reduced by the GPO (this figure does not include persons who were eligible for spousal benefits but were deterred from filing for them because of GPO.” (Congressional Research Service, 2013, p. 3). Notice that GPO applies to government workers, while WEP applies to those who worked in any uncovered employment. ${ }^{5}$

\footnotetext{
${ }^{2}$ There is a similar problem in the case of immigrants, but policy has not been changed to address the problem. Gustman and Steinmeier (2000) show that immigrants who spend fewer years in covered employment than U.S. born enjoy a higher rate of return on their payroll taxes paid than do U.S. born with comparable annual earnings. Indeed, immigrants with high annual earnings, but only a decade or so of covered employment, enjoy up to a ninety percent replacement rate on the FICA taxes they pay, despite having similar annual earnings and wealth as native born. Gustman and Steinmeier also discuss a simple policy fix for this problem.

${ }^{3}$ According to data cited in Brown and Weisbenner, "Approximately one fourth of all public employees in the U.S. do not pay Social Security taxes on the earnings from their government job (U.S. GAO, 2007). This includes approximately 5.25 million state and local workers, as well as approximately 1 million federal employees hired before 1984 (U.S. GAO, 2003)."

${ }^{4}$ According to the GAO: "About $2.4 \%$ of all Social Security beneficiaries (including disabled and spouse beneficiaries), and about 4\% of all retired worker beneficiaries, were affected by the WEP in December 2012.” (Congressional Research Service, 2013a, p. 3)

${ }^{5}$ We show below that respondents have difficulty in determining whether they work for the government or not. Consequently, we apply the GPO adjustment whenever the job is reported as not covered by Social Security.
} 
In the absence of the Government Pension Offset, a spouse or survivor of a covered worker, where the spouse worked in uncovered government employment, would be treated more favorably than the spouse of a covered worker, where that spouse worked only in covered employment (Diamond and Orszag, 2003). The reason is that when both spouses have covered earnings, dual entitlement provisions apply. Under dual entitlement, the total benefits paid to a spouse who is entitled both to benefits based on own covered work and to spouse benefits will be the higher of the two benefits. That is, where spouse benefits (roughly half the benefit of the primary earner) are greater than benefits from own work, the spouse benefit "tops up" the benefit from own work. Similarly, the total paid to a survivor is the greater of benefits to be received as a survivor (the benefit of the primary earner) or the benefit based on the survivor's own covered work. Again the survivor benefit is paid as a "top up" over own benefits. In contrast, consider the situation of a spouse who earned a pension from a lifetime of uncovered work. In the absence of GPO, the uncovered worker would be eligible for the full Social Security spouse or survivor benefit from their covered spouse’s employment. (Social Security Administration, 2012) ${ }^{6}$ Empirical studies of WEP and GPO have been conducted by government agencies, such as SSA, GAO and the Congressional Research Service. These studies are based on administrative data. Typically, they report the number of individuals affected by WEP and GPO and the dollar values of these offsets for each individual. However, administrative data have not been used to analyze the impact of WEP and GPO at the household level. Without household level data, it is not possible to analyze the interactions of WEP and GPO. Nor is it possible to evaluate WEP and GPO adjustments in relation to household pensions and total wealth accumulated around retirement age.

This paper uses data from the Health and Retirement Study (HRS) to estimate the effects of WEP and GPO at the household level. Our analysis uses respondent provided work histories

${ }^{6}$ There is another type of inequity that the Government Pension Offset creates. Consider households with three different types of earnings records. In household 1 , in line with the traditional model of a family in vogue when Social Security was first adopted, all work is undertaken by a primary earner in the private sector in covered employment. By design of the system, with some minor adjustments, a spouse who never worked is entitled to half the benefit paid the primary earner in the household, and to the full benefit should the primary earner die. In household 2, one spouse works in uncovered employment and earns a pension, while the other works in covered employment. The member of the couple from household 2 who works in uncovered employment and earns a pension may lose spouse and survivor benefits due to the Government Pension Offset. This would appear to be unfair relative to household 1 , where only one spouse works. Neither of the spouses with no covered earnings paid any payroll taxes, but household 2, where one spouse worked in government employment and earned a pension, will receive a much smaller spouse or survivor benefit, if any, than the spouse in household 1 , who did not work at all. 
and administrative earning records to estimate the covered and uncovered earnings histories of each spouse, evaluates pensions from any uncovered jobs, imputes missing data, and then uses the Social Security Administration's ANYPIA program to estimate benefits before and after the WEP and GPO provisions are applied. HRS allows us to relate WEP and GPO adjustments that are called for under current law to the values of their Social Security and pensions from covered and uncovered employment, and to relate these adjustments, as well as the total benefits from Social Security and pensions, to the total wealth accumulated by households on the verge of retiring.

Before turning to our analysis, note two important caveats. First, we are projecting WEP and GPO adjustments on the basis of current law, reported covered and uncovered earnings, and expected claiming dates, and reported pensions from uncovered work. We do not have direct observations of WEP and GPO adjustments among a population that has already retired. ${ }^{7}$ Second, this paper analyzes the first round effects of these policies. We do not include behavioral responses to WEP and GPO as affected respondents and members of their households react to the incentives created by the policies.

Section II further discusses WEP and GPO. Section III discusses the variables needed to estimate WEP and GPO adjustments with data from the Health and Retirement Study (HRS), and the reasons for the mixed approach we take in using respondent and administrative data. Section IV calculates the basic measures of employment, earnings and coverage required to determine the incidence of WEP and GPO. Section V analyzes the effects of WEP and GPO on Social Security benefits. Section VI disaggregates the effects of WEP into changes in benefits resulting a) from the reduction in the generosity coefficient through the first bend point in the AIME formula from 90 percent to as low as 40 percent; and b) from the effects of adjustments associated with pensions earned in uncovered employment. Section VII concludes.

\footnotetext{
${ }^{7}$ An SSA description of one particular type of administrative data file, one that reports the information from the W2 form, notes: "With EPUF, it is also not possible to adjust benefits for workers subject to the Windfall Elimination Provision, which reduces benefits of individuals who have only minimal Social Security coverage and will receive a pension based on years of work in non-covered employment" (SSA, 2012). Compson (2011, footnote 25) indicates "SSA cannot determine married-couple or parent-child relationships in the file based on the information derived from the MEF. SSA establishes such linkages after an individual applies for benefits. In any event, linking currently or previously married individuals or indicating a familial relationship in EPUF would create serious data disclosure risks.”
} 


\section{Further Discussion of WEP and GPO}

\section{WEP and GPO Interactions at the Household Level}

To set the stage for the calculation of the actual WEP and GPO adjustments found in data from the Health and Retirement Study, Table 1 presents twelve scenarios. For each scenario, Table 1A indicates own benefits of the wife in couple households, or of a single woman in a one person household, the spouse benefits received by the wife, and the survivor benefits received by the wife. The table shows own, spouse and survivor benefits for the woman under various combinations of previous employment by the husband and wife. Table 1B keeps the combinations of work by the husband and wife the same. It indicates own benefits of the husband, the spouse benefits that may accrue to some husbands based on their wife's employment, and the survivor benefits accruing to some husbands.

The scenarios are listed in columns 1 and 2 of the table. Scenarios involve different combinations of employment in the public and private sectors, as well as nonemployment. Each spouse may have worked long enough in a job covered by Social Security to be entitled to benefits, worked in a job not covered by Social Security, and/or earned a pension in a job not covered by Social Security, or not worked long enough in any job to qualify for Social Security benefits. Column 1 describes the work history of the male in the household; column 2 describes the work history for the female, where in all but Scenario 11, the household includes a husband and wife.

Column 3 in each table indicates whether WEP applies in determining own benefits. Columns 4 and 5 report the top up over own benefits from spouse and survivor benefits. The "top up” is the additional benefit paid under dual entitlement beyond the "own benefit” earned by the indicated individual. The top up will be paid on the basis of the each spouse's earnings and pension history. 
Table 1A: Scenarios for Husbands and Wives in Covered and/or Non-covered Employment for Calculating the Wife’s Own, Spouse and Survivor Benefits*

\begin{tabular}{|c|c|c|c|c|}
\hline Husband & Wife & $\begin{array}{l}\text { Wife's Own } \\
\text { Benefit }\end{array}$ & $\begin{array}{l}\text { Wife's Spouse benefit } \\
\text { (top-up) }\end{array}$ & $\begin{array}{l}\text { Wife's Survivor benefit } \\
\text { (top-up) }\end{array}$ \\
\hline $\begin{array}{l}\text { Scenario } 1 \\
\text {-Non-covered earnings } \\
\text { With pension } \\
\text {-Covered earnings With SS ben \& } \\
\text { spouse \& survivor benefits }\end{array}$ & -No earnings & None & $\begin{array}{l}\text { Top-up= Spouse benefit after } \\
\text { WEP }\end{array}$ & Top-up= Survivor benefit before WEP \\
\hline $\begin{array}{l}\text { Scenario } 2 \\
\text {-Non-covered earnings } \\
\text { With pension } \\
\text {-Covered earnings With SS ben \& } \\
\text { spouse \& survivor benefits }\end{array}$ & -Covered earnings & $\begin{array}{l}\text { WEP does } \\
\text { not apply }\end{array}$ & $\begin{array}{l}\text { i. Spouse's own benefit } \\
\text { ii. Spouse benefit after WEP* } \\
\text { if ii > i then: } \\
\text { Top-up = ii - i }\end{array}$ & $\begin{array}{l}\text { i. Spouse's own benefit } \\
\text { ii. Survivor benefit before WEP } \\
\text { if ii > i then: } \\
\text { Top-up = ii - i }\end{array}$ \\
\hline $\begin{array}{l}\text { Scenario } 3 \\
\text {-Covered earnings } \\
\text { With SS benefits \& spouse \& survivor } \\
\text { benefits }\end{array}$ & $\begin{array}{l}\text {-Non-covered earnings } \\
\text { With pension }\end{array}$ & None & $\begin{array}{l}\text { Top-up= Spouse benefit }-2 / 3 * \\
\text { her pension }\end{array}$ & $\begin{array}{l}\text { Top-up= Survivor benefit before GPO - 2/3* } \\
\text { her pension }\end{array}$ \\
\hline $\begin{array}{l}\text { Scenario } 4 \\
\text {-Covered earnings } \\
\text { With SS benefits \& spouse \& survivor } \\
\text { benefits }\end{array}$ & $\begin{array}{l}\text {-Non-covered earnings } \\
\text { With pension \& } \\
\text {-Covered earnings With SS } \\
\text { ben \& spouse \& survivor } \\
\text { benefits }\end{array}$ & After WEP & $\begin{array}{l}\text { i. Spouse's own benefit after } \\
\text { WEP } \\
\text { ii. Spouse benefit (noWEP)-2/3 } \\
\text { * her pension } \\
\text { if ii > i then: Top-up = ii - i }\end{array}$ & $\begin{array}{l}\text { i- Spouse's own benefit after WEP } \\
\text { ii- Survivor benefit before GPO- } 2 / 3 * \text { her } \\
\text { pension } \\
\text { if ii > i then: } \\
\text { Top-up = ii - i }\end{array}$ \\
\hline $\begin{array}{l}\text { Scenario } 5 \\
\text {-Non-covered earnings } \\
\text { With pension } \\
\text {-Covered earnings With SS ben \& } \\
\text { spouse \& survivor benefits }\end{array}$ & $\begin{array}{l}\text {-Non-covered earnings } \\
\text { With pension }\end{array}$ & None & $\begin{array}{l}\text { i. Spouse benefit after WEP } \\
\text { ii. } 2 / 3 * \text { her pension } \\
\text { if } \mathrm{i}>\text { ii then: } \\
\text { Top-up = } \mathrm{i}-\mathrm{ii}\end{array}$ & $\begin{array}{l}\text { i. Survivor benefit before WEP } \\
\text { ii. } 2 / 3 \text { * her pension } \\
\text { if } \mathrm{i}>\text { ii then: } \\
\text { Top-up= } \mathrm{i} \text { - ii }\end{array}$ \\
\hline $\begin{array}{l}\text { Scenario } 6 \\
\text {-Non-covered earnings } \\
\text { With pension } \\
\text {-Covered earnings With SS ben \& } \\
\text { spouse \& survivor benefits }\end{array}$ & $\begin{array}{l}\text {-Non-covered earnings } \\
\text { With pension \& } \\
\text {-Covered earnings With SS } \\
\text { ben \& spouse \& survivor } \\
\text { benefits }\end{array}$ & After WEP & $\begin{array}{l}\text { i. Spouse's own benefit after } \\
\text { WEP } \\
\text { ii. Spouse benefit after WEP - } \\
2 / 3 \text { * her pension } \\
\text { if ii > i then: Top-up = ii - i }\end{array}$ & $\begin{array}{l}\text { i-Spouse's own benefit after WEP } \\
\text { ii- Survivor benefit before WEP- } 2 / 3 * \text { her } \\
\text { pension } \\
\text { if ii > i then: Top-up = ii - i }\end{array}$ \\
\hline $\begin{array}{l}\text { Scenario } 7 \\
\text { - No earnings }\end{array}$ & $\begin{array}{l}\text {-Non-covered earnings } \\
\text { With pension }\end{array}$ & After WEP & None & None \\
\hline
\end{tabular}




\begin{tabular}{|c|c|c|c|c|}
\hline Husband & Wife & $\begin{array}{l}\text { Wife's Own } \\
\text { Benefit }\end{array}$ & $\begin{array}{l}\text { Wife's Spouse benefit } \\
\text { (top-up) }\end{array}$ & $\begin{array}{l}\text { Wife's Survivor benefit } \\
\text { (top-up) }\end{array}$ \\
\hline & $\begin{array}{l}\text {-Covered earnings With SS } \\
\text { ben } \& \text { spouse \& survivor } \\
\text { benefits }\end{array}$ & & & \\
\hline $\begin{array}{l}\text { Scenario } 8 \\
\text {-Non-covered earnings with pension }\end{array}$ & $\begin{array}{l}\text {-Covered earnings } \\
\text { With SS benefits \& spouse } \\
\text { \& survivor benefits }\end{array}$ & $\begin{array}{l}\text { WEP does } \\
\text { not apply }\end{array}$ & None & None \\
\hline $\begin{array}{l}\text { Scenario } 9 \\
\text {-Non-covered earnings with pension }\end{array}$ & $\begin{array}{l}\text {-Non-covered earnings } \\
\text { With pension } \\
\text {-Covered earnings With SS } \\
\text { ben \& spouse \& survivor } \\
\text { benefits }\end{array}$ & After WEP & None & None \\
\hline $\begin{array}{l}\text { Scenario } 10 \\
\text { Widow: } \\
\text { Scenario } 1 \text { - Scenario } 9 \\
\end{array}$ & Scenario 1 - Scenario 9 & $\begin{array}{l}\text { Scenario } 1 \text { - } \\
\text { Scenario } 9 \\
\end{array}$ & None & Scenario 1 - Scenario 9 \\
\hline Scenario 11 & $\begin{array}{l}\text { Never married } \\
\text {-Covered earnings OR } \\
\text {-Non-covered earnings } \\
\text { OR } \\
\text { - Both covered and Non- } \\
\text { covered earnings } \\
\text { - }\end{array}$ & $\begin{array}{l}\text { - WEP does } \\
\text { not apply } \\
\text {-No benefit } \\
\text {-After WEP }\end{array}$ & No spouse benefit & No survivor benefit \\
\hline $\begin{array}{l}\text { Scenario } 12 \\
\text { - Covered earnings with SS benefits \& } \\
\text { spouse \& survivor benefits } \\
\text { Or } \\
\text { No earnings }\end{array}$ & $\begin{array}{l}\text {-Covered earnings with SS } \\
\text { benefits } \& \text { spouse } \& \\
\text { survivor benefits } \\
\text { Or } \\
\text { No earnings }\end{array}$ & $\begin{array}{l}\text { WEP does } \\
\text { not apply }\end{array}$ & WEP and GPO do not apply & WEP and GPO do not apply \\
\hline
\end{tabular}

* Total spouse or survivor benefit equals own benefit plus top-up. The WEP adjustment uses a replacement rate as low as 40 percent (depending on the number of years of covered work) up to the first bend point when calculating Social Security benefits instead of the 90 percent replacement rate called for by the PIA formula. The WEP adjustment to Social Security benefits cannot exceed half of the pension earned in uncovered employment. GPO reduces Social Security spouse and survivor benefits up to $2 / 3$ of the value of pensions from own uncovered employment. 
Table 1B: Scenarios for Husbands and Wives in Covered and/or Non-covered Employment for Calculating the Husband's Own, Spouse and Survivor Benefits*

\begin{tabular}{|c|c|c|c|c|}
\hline Husband & Wife & $\begin{array}{l}\text { Husband's } \\
\text { Own Benefit }\end{array}$ & $\begin{array}{c}\text { Husband's Spouse benefit } \\
\text { (top-up) }\end{array}$ & Husband's Survivor benefit (top-up) \\
\hline $\begin{array}{l}\text { Scenario } 1 \\
\text {-Non-covered earnings } \\
\text { With pension } \\
\text {-Covered earnings With SS ben \& } \\
\text { spouse \& survivor benefits } \\
\end{array}$ & -No earnings & After WEP & None & None \\
\hline $\begin{array}{l}\text { Scenario } 2 \\
\text {-Non-covered earnings } \\
\text { With pension } \\
\text {-Covered earnings With SS ben \& } \\
\text { spouse \& survivor benefits }\end{array}$ & -Covered earnings & After WEP & $\begin{array}{l}\text { i. Husband's own benefit after } \\
\text { WEP } \\
\text { ii. Spouse benefit from wife } \\
\text { (noWEP)-2/3 * his pension } \\
\text { if ii > i then: } \\
\text { Top-up = ii - i }\end{array}$ & $\begin{array}{l}\text { i. Husband's own benefit after WEP } \\
\text { ii. Survivor benefit from wife (noWEP)-2/3 * his } \\
\text { pension } \\
\text { if ii > i then: } \\
\text { Top-up = ii - i }\end{array}$ \\
\hline $\begin{array}{l}\text { Scenario } 3 \\
\text {-Covered earnings } \\
\text { With SS benefits \& spouse \& } \\
\text { survivor benefits }\end{array}$ & $\begin{array}{l}\text {-Non-covered earnings } \\
\text { With pension }\end{array}$ & No WEP & None & 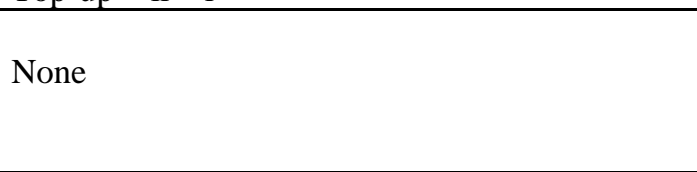 \\
\hline $\begin{array}{l}\text { Scenario } 4 \\
\text {-Covered earnings } \\
\text { With SS benefits \& spouse \& } \\
\text { survivor benefits }\end{array}$ & $\begin{array}{l}\text {-Non-covered earnings } \\
\text { With pension \& } \\
\text {-Covered earnings With } \\
\text { SS ben \& spouse \& } \\
\text { survivor benefits }\end{array}$ & No WEP & $\begin{array}{l}\text { i. Husband's own benefit No } \\
\text { WEP } \\
\text { ii. Spouse benefit from wife } \\
\text { (after WEP) } \\
\text { if ii > i then: Top-up = ii - i }\end{array}$ & $\begin{array}{l}\text { i. Husband's own benefit No WEP } \\
\text { ii. Survivor benefit from wife (No WEP) } \\
\text { if ii > i then: } \\
\text { Top-up = ii - i }\end{array}$ \\
\hline $\begin{array}{l}\text { Scenario } 5 \\
\text {-Non-covered earnings } \\
\text { With pension \& } \\
\text {-Covered earnings With SS ben \& } \\
\text { spouse \& survivor benefits } \\
\end{array}$ & $\begin{array}{l}\text {-Non-covered earnings } \\
\text { With pension }\end{array}$ & After WEP & None & None \\
\hline $\begin{array}{l}\text { Scenario } 6 \\
\text {-Non-covered earnings } \\
\text { With pension } \\
\text {-Covered earnings With SS ben } \\
\text { \& spouse \& survivor benefits }\end{array}$ & $\begin{array}{l}\text {-Non-covered earnings } \\
\text { With pension \& } \\
\\
\text {-Covered earnings With } \\
\text { SS ben \& spouse \& } \\
\text { survivor benefits }\end{array}$ & After WEP & $\begin{array}{l}\text { i. Husband's own benefit after } \\
\text { WEP } \\
\text { ii. Spouse benefit from wife after } \\
\text { WEP - } 2 / 3 * \text { his pension } \\
\text { if ii > i then: Top-up = ii - i }\end{array}$ & $\begin{array}{l}\text { i. Husband's own benefit after WEP } \\
\text { ii. Survivor benefit from wife (No WEP) - 2/3 * } \\
\text { his pension } \\
\text { if ii > i then: Top-up = ii - i }\end{array}$ \\
\hline
\end{tabular}




\begin{tabular}{|c|c|c|c|c|}
\hline Husband & Wife & $\begin{array}{l}\text { Husband's } \\
\text { Own Benefit }\end{array}$ & $\begin{array}{l}\text { Husband's Spouse benefit } \\
\text { (top-up) }\end{array}$ & Husband's Survivor benefit (top-up) \\
\hline $\begin{array}{l}\text { Scenario } 7 \\
\text { - No earnings }\end{array}$ & $\begin{array}{l}\text {-Non-covered earnings } \\
\text { With pension } \\
\text {-Covered earnings With } \\
\text { SS ben \& spouse \& } \\
\text { survivor benefits }\end{array}$ & None & $\begin{array}{l}\text { Top-up= Spouse benefit from } \\
\text { wife after WEP }\end{array}$ & $\begin{array}{l}\text { Top-up= Survivor benefit from wife before } \\
\text { WEP }\end{array}$ \\
\hline $\begin{array}{l}\text { Scenario } 8 \\
\text {-Non-covered earnings with } \\
\text { pension }\end{array}$ & $\begin{array}{l}\text {-Covered earnings } \\
\text { With SS benefits \& } \\
\text { spouse \& survivor } \\
\text { benefits }\end{array}$ & None & $\begin{array}{l}\text { Spouse benefit from wife } \\
\text { (noWEP)-2/3* his pension }\end{array}$ & $\begin{array}{l}\text { Survivor benefit from wife (noWEP)-2/3 * his } \\
\text { pension }\end{array}$ \\
\hline $\begin{array}{l}\text { Scenario } 9 \\
\text {-Non-covered earnings with } \\
\text { pension }\end{array}$ & $\begin{array}{l}\text {-Non-covered earnings } \\
\text { With pension } \\
\text {-Covered earnings With } \\
\text { SS ben \& spouse \& } \\
\text { survivor benefits } \\
\end{array}$ & None & $\begin{array}{l}\text { Spouse benefit from wife after } \\
\text { WEP }-2 / 3 * \text { his pension }\end{array}$ & $\begin{array}{l}\text { Survivor benefit from wife (noWEP)-2/3 * his } \\
\text { pension }\end{array}$ \\
\hline $\begin{array}{l}\text { Scenario } 10 \\
\text { Widower: } \\
\text { Scenario } 1 \text { - Scenario } 9\end{array}$ & Scenario 1 - Scenario 9 & $\begin{array}{l}\text { Scenario } 1 \text { - } \\
\text { Scenario } 6\end{array}$ & Scenario 1 - Scenario 9 & Scenario 1 - Scenario 9 \\
\hline $\begin{array}{l}\text { Scenario } 11 \\
\text { Never married } \\
\text {-Covered earnings OR } \\
\text {-Non-covered earnings OR } \\
\text { - Both covered and Non- } \\
\text { covered earnings }\end{array}$ & - & $\begin{array}{l}\text { - No WEP } \\
\text { - No benefit } \\
\text {-After WEP }\end{array}$ & No spouse benefit & No survivor benefit \\
\hline $\begin{array}{l}\text { Scenario } 12 \\
\text { - Covered earnings with SS } \\
\text { benefits \& spouse \& survivor } \\
\text { benefits } \\
\text { Or } \\
\text { No earnings } \\
\end{array}$ & $\begin{array}{l}\text {-Covered earnings with } \\
\text { SS benefits \& spouse \& } \\
\text { survivor benefits } \\
\text { Or } \\
\text { No earnings }\end{array}$ & No WEP & WEP and GPO do not apply & WEP and GPO do not apply \\
\hline
\end{tabular}

* Total spouse or survivor benefit equals own benefit plus top-up. The WEP adjustment uses a 40 percent replacement rate up to the first bend point when calculating Social Security benefits instead of the 90 percent replacement rate called for by the PIA formula. The WEP adjustment to Social Security benefits cannot exceed half of the pension earned in uncovered employment. GPO reduces Social Security spouse and survivor benefits up to 2/3 of the value of pensions from own uncovered employment. 
For example, in Scenario 1, the husband worked in an uncovered job with a pension and also gained entitlement to Social Security benefits from covered employment. The wife had no substantial earnings history either in a covered or an uncovered job. (Scenario 7 flips the employment of each spouse so that the wife worked in an uncovered job with a pension, and also gained entitlement to Social Security, while the husband had no substantial earnings.) Thus in Table 1A, Scenario 1, the wife had no own benefits. From Table 1B, the husband's own benefits are adjusted by WEP. From Table 1A, the top up for the wife is equal to the full spouse benefit based on her husband's work after adjusting for WEP; and the top up to the survivor benefit is equal to the full value of her survivor benefit based on her husband's work, not adjusted for WEP. Analogous results are shown for Scenario 7.

To take a more complicated example, in Scenario 6, both the husband and wife worked in an uncovered job with a pension, and also gained entitlement to Social Security benefits from covered employment. For each spouse, own benefits are first adjusted by WEP. For the wife, the top up to the spouse benefit based on her husband's work in covered employment starts with half his benefit after WEP, from which her own benefits are subtracted, with two thirds of the pension from her own uncovered work then subtracted from the remainder. The top up in her survivor benefits starts with her husband's full benefit not adjusted for WEP, less her own benefits, with two thirds of her pension from her own uncovered work subtracted from the remainder. The analogous calculation is used to determine any top up to the husband's own benefit after WEP due to the spouse and survivor benefit from the wife's covered earnings.

\section{Pensions from Uncovered Work Limit WEP and GPO Adjustments}

Congress did not go as far as it might have in setting the WEP and GPO limitations on Social Security benefits. With regard to WEP, Congress recognized that because of the progressivity of the benefit formula, those who spend part of their career in uncovered work receive a proportionately better deal from Social Security. Nevertheless, Congress was unwilling to mechanically reduce basic Social Security benefits just because a person had also worked in uncovered employment. ${ }^{8}$ That is, Social Security benefits are not reduced simply because a

\footnotetext{
${ }^{8}$ A part of the reason had to do with difficulties of measuring the value of earning from uncovered employment. Brown and Weisbenner (2012, p. 6) point out that the Social Security Administration did not collect
} 
person who worked in uncovered employment consequently receives a higher ratio of Social Security benefits to Social Security taxes paid. The potentially affected individual must also have earned a pension from uncovered work for benefits to be reduced under WEP. Then the benefit reduction is limited to half the value of the pension from uncovered work. We will show below that limiting the WEP adjustment to half the value of a public pension earned reduces the WEP offset by more than half.

Nor would Congress augment the GPO adjustment to reduce spouse or survivor benefits simply because a spouse of an entitled worker had spent a significant amount of time in an uncovered job. Once again, the adjustment is made only if the individual also earned a pension from working in uncovered employment.

In sum, Congress drew the line at what it perceived to be “double dipping”. If, in addition to working long enough on a covered job to become eligible for Social Security benefits, a person worked in uncovered employment, and that person also received a pension from their uncovered job, the individual's Social Security benefits, and benefits to be paid to the spouse or survivor of that individual, would be adjusted downward. ${ }^{9}$ Otherwise, there would be no adjustment. Similarly, spouse and survivor benefits are adjusted downward for those whose own work was in a job not covered by Social Security. Once again, however, spouse and survivor benefits are reduced only if that individual also earned a pension from uncovered employment.

\section{Opposition to WEP and GPO Continues}

Congress' decision not to reduce the Social Security benefits of those who worked in uncovered employment, individuals who avoided payroll taxes, but did not receive a pension from their uncovered work, did not eliminate opposition to WEP and GPO. Many affected government workers resent WEP and GPO adjustments to their Social Security benefits. State and local and other government employee associations continue to lobby, asking Congress to eliminate these adjustments to their Social Security benefits.

One reason for this resentment is that the reduction in Social Security benefits called for by the WEP formula can be substantial, at least at the limit. In the case of WEP, in 2013 the

data on earnings from uncovered employment before 1978. As a result, SSA could not adjust benefits for uncovered earnings in any year before then.

${ }^{9}$ Congress tempers the reduction in benefits for those who, despite having worked in uncovered employment, worked for many years in covered employment. The penalty from WEP is reduced if the individual worked in covered employment for more than twenty years, with the entire penalty eliminated if the individual was covered by Social Security for at least thirty years. For those with between 20 and 30 years in covered employment, the Social Security benefit is reduced on a prorated basis. 
Social Security benefit is reduced by lowering the replacement rate for the first $\$ 9,492$ of covered earnings from 90 percent to (as low as) 40 percent. This adjustment reduces the associated benefit from $\$ 8,543$ per year to $\$ 3,797$ per year, or by up to $\$ 4,746$ per year. (For a reduction of this size to be imposed through WEP, the pension from uncovered work would have to be twice as large, or $\$ 9,492$.) Under GPO, the reduction may be up to two thirds of the value of the pension in uncovered work, and may wipe out the spouse or survivor benefit entirely. In the case of the survivor benefit, that may entail a loss in the tens of thousands of dollars for a surviving spouse who spent a full lifetime in uncovered employment (e.g., a public school teacher).

\section{The Data}

Our analysis is based on data from the Health and Retirement Study (HRS). In its first wave the HRS interviewed 12,652 respondents from households with at least one member between the ages of 51 and 61 in 1992. Respondents have been interviewed every other year since. New cohorts were added in 1998 (Warbabies); 2004 (Early Boomers) and 2010 (Mid Boomers), consisting of individuals from households with at least one person age 51 to 56 in the base year for each new cohort. Our study focuses on the original HRS cohort and on the Early Boomers. Social Security earnings records are not available for the Mid Boomers at the time this paper is being written. Thus the HRS cohort and the Early Boomer cohorts are the earliest and latest cohorts that include the required data.

Employment history, coverage by Social Security and pension coverage are reported in the respondent interview. During the baseline survey, respondents were asked about their current job, last job if not currently employed, the most recent previous job lasting five or more years, and two additional previous jobs lasting at least five years that offered a pension. In this first interview, respondents were also asked whether they ever worked for the government at the state, local or federal level. In the third wave for the original HRS cohort, they were asked about work on a job that was not covered by Social Security. In 2004, all respondents were asked additional questions on coverage by Social Security and in 2006 whether they worked for a federal, state or local government. Information collected on the start and end dates of jobs allow us to match the period of employment with the type of employer, coverage by Social Security, and coverage by a pension. 
Matched administrative records provided by The Social Security Administration report covered earnings in each year of work. Most respondents gave permission for the HRS to obtain their Social Security records, and additional permissions were obtained in subsequent waves both to allow updating and to obtain records for respondents who at first denied permission.

In addition to records on covered earnings, W2 records are also available. They provide information on covered and uncovered earnings dating from 1978. Box 1 of the W2 record reports total earnings, while box 3 reports earnings covered by Social Security. Earnings from self-employment and earnings from employment not covered by Social Security (non-FICA earnings) are also reported. We have used these data together with self-reports to identify jobs that were not covered by Social Security. ${ }^{10}$

Own Social Security benefits from working on a covered job are calculated by applying the Social Security Administration's ANYPIA program to the covered earning records for the respondent. When records are not available from the Social Security Administration, we impute them based on individual and job characteristics, including self-reported earnings. Once the values of own benefits are calculated, the respondents are merged into households. Own, spouse and survivor benefits are calculated at the household level. For households where there was some work in both covered and uncovered employment, where at least on party was entitled to Social Security benefits, and one or another had a pension from uncovered work, the WEP and GPO adjustments for the household members are calculated.

10 There are some internal inconsistencies in a minority of W2 records. To highlight the nature of these inconsistencies, we constructed a sample of respondents who, by 1992, had worked at least 10 years on their current job (this restriction eliminates complications from job changing and holding of multiple jobs within the year), and eliminated the self-employed. We then looked for anomalies within this sample. As a first puzzle, we found in 4.3 percent of respondent-year observations total W2 earnings are positive, but covered earnings (box 3) and non-FICA earnings are zero. A second puzzle, in 1.3 percent of observations, while covered earnings and/or non-FICA earnings are positive, total earnings are reported as zero. Third, for those with no job change, there are anomalous changes in covered and non-FICA earnings between waves.

We should also note that self-employment earnings are not consistently reported over the full period. In particular, before 1993, self-employment earnings might be only partially reported. In 1993, the cap on payroll subject to the Medicare tax was lifted. Before then, if a person had earnings as an employee, where the earning were subject to the payroll tax, while also having self-employment income, self-employment income was only reported until the sum of total earnings reached maximum covered earnings for determining Social Security payroll tax payments. Thus a person with a relatively well paid job who also worked in self-employment might not have the full self-employment income reported. Since employee earnings took precedence, for those with taxable earnings at the maximum, earnings from self-employment would vary inversely with the level of employee earnings. Fortunately, from the perspective of our study, the only values we require from the Social Security records are reports on covered earnings, whether they are from employment or self-employment. 
Recall that WEP adjustments are limited to half the value of pensions from uncovered work, and GPO adjustments are limited to two thirds of the value of the dependent spouse's pension from uncovered work. Pension data are taken from respondent self-reports. Based on HRS reports as to employer, we determine whether the pension is from covered or from uncovered employment. Pension values are calculated for DB plans based on reported benefits at expected retirement dates, monthly pensions if the plan was already in pay status, and IRA accounts and monthly annuities that had been rolled over at termination. SSA provides a formula for converting DC pensions and lump sum pension settlements into a flow. For pensions from current jobs in the baseline period we used the pension values at termination if that job was terminated after 1992 for the original HRS cohort and after 2004 for the Early Boomers.

Significant errors in reporting of government employment limit our ability to identify government employees. More specifically, for reasons we discuss below, it will turn out that only half of respondents who report they worked in a job not covered by Social Security will also report they were government employees. ${ }^{11}$

\section{Employment, Earnings and Coverage by WEP and GPO}

Throughout this paper, those affected by WEP are identified as the subpopulation who worked in employment not covered by Social Security, who also worked in employment subject to FICA taxes and earned enough to be covered by Social Security (ten years of covered quarters), and who had a pension from their uncovered employment.

We use reported dates of employment or tenure to identify jobs, to determine whether or not those jobs are covered by Social Security, and to associate pensions with particular jobs.

After calculating earnings from covered and uncovered work at the individual level, we aggregate up to the household. Households are separated into those that are subject to WEP provisions, to GPO provisions, to both sets of provisions, and those that are not. This requires identifying households where one or both members worked in uncovered employment; using both the longitudinal feature of the HRS as well as detailed reporting of work on more than one job to identify those households where some work was also in covered employment and was sufficient to generate Social Security benefits; and to determine in which households with both covered and uncovered employment, the uncovered work also generated a pension.

\footnotetext{
${ }^{11}$ Agricultural workers and railroad employees are not subject to Social Security. There are only a few individuals with these occupations in our sample.
} 
To provide a clearer picture of our procedures, consider the data in Table 3. The top panel pertains to members of the 1992 HRS cohort, and the bottom panel to the Early Boomer cohort. Upon entry into the survey, respondents were asked about their employment status. Column reports the number who reported being employed either currently or in the past. Since these respondents were followed after the initial wave, we add information on any new jobs held subsequent to the initial interview. Rows 2 and 4 report the number of respondents in the HRS cohort and in the Early Boomer cohort who reported ever being employed.

Given the central role played by pensions in WEP and GPO adjustments, rows 1 and 3 report the number in each cohort ever covered by a pension. At this stage we do not identify pensions that were lost or cashed out upon leaving the job and distinguish them from pensions that were live at the time Social Security benefits were determined.

Of respondents who were ever employees, 7,480/10,703 (2,241/2,906), or 69.9 (77.1) percent reported having a pension on at least one of their jobs. As in Gustman, Steinmeier and Tabatabai (2010), many more workers have ever been covered by a pension than is suggested by coverage rates from surveys of the general population, or of employers, asking about coverage on a current job only, where roughly half report pension coverage.

Column 2 then indicates the number who reported they were ever employed by a unit of the state, county, local or federal government (questions H61 and H62 in Wave 1). Note that there is considerable ambiguity in determining government employment, especially for respondents. Thus some respondents may not report they are, or have been, state or local government employees even though they participate in state or local pension plans. Notable examples may include employees of state universities, libraries and other state or locally funded services where the employee's salary check is not directly paid by a state or local government agency, or is not obviously funded by the government, such as police or fire. ${ }^{12}$ There may even be ambiguity on the part of some elementary or secondary school teachers.

${ }^{12}$ It is easy to see why some respondents may classify a job that is not directly for a state or local government agency, but nevertheless involves working in a publically supported institution that is part of the state retirement system, as not involving government employment, while correctly noting the job is not covered by Social Security. Consider again a person who works for a state university and thus does not work directly for the state. Tuition may be as important, or more important, as a source of revenue for the university than direct support from the state. In such a case, it is not clear how a respondent should be classified with regard to government employment, let alone how respondents themselves should classify whether they work for the government or not. 
The reported dates of government employment are matched with the respondent's employment history to identify whether a particular job involved government employment. That is, each respondent reports the dates for current, last or previous jobs, and also reports the dates worked in various levels of government employment. We allow an error of plus or minus 3 years on each end of the job report when declaring a job to be a match. A total of 2,168 (681) respondents report ever having worked for a government, representing 20.3 (23.4) percent of the $10,703(2,906)$ respondents who reported ever being employed.

Column 3 reports employment in jobs not covered by Social Security. In wave 3 respondents from the original HRS cohort were asked (question G164) about employment in any job where Social Security (FICA) taxes were not paid. Once again, jobs not covered by Social Security were matched with jobs held according to reported dates of employment. Among the $10,703(2,906)$ respondents who reported ever being an employee, 895/10,703 (239/2,906), or 8.4 (8.2) percent reported ever holding a job that was not covered by Social Security.

As an intermediate step to help distinguish reported government employment from reported uncovered employment, we construct column 6, which reports the number of respondents who either indicated they were government employees, or who said they were not covered by Social Security, or both. The total of government employees plus non-covered employees, counting the overlap between these groups twice, is 3,063 $=2168+895$ (920 $=681$ + 239). The total of employees who reported working in either government employment, or noncovered employment, counting overlaps only once is 2,649 (762). So the total number who both worked for the government and were not covered by Social Security is $414=3,063-2,649$ (158 $=920-762)$. This means that $481=895-414(81=239-158)$, or 481/895 $(81 / 239)$ or 53.7 (33.9) percent of the employees who reported having a job that was not covered by Social Security, did not report working for the government. Analogously, 19.1 percent = 414/2,168 $(23.2$ percent $=158 / 681)$ of government workers reported not being covered by Social Security. ${ }^{13}$ To the extent that government employment is understated, but work in jobs not covered by Social Security is reported accurately, the ratio of uncovered employees to government employees will be too high.

${ }^{13}$ The GAO (2010) report that 73 percent of state and local government employees are covered by Social Security is based on administrative data supplied by the Social Security Administration. 
Next we consider pension coverage among the various groups. Our particular concern is with those individuals who were covered by a pension on a job not covered by Social Security. From row 2 (and 4) of Table 3, 7,480/10,703 = 69.9 percent $(2,241 / 2,906=77.1$ percent) of all employed individuals ever had a pension, that is, had a pension on at least one job. Among those reporting they worked in government employment, the ratio of pension covered to noncovered workers is .882 =1,914/2,168 $(.891=607 / 681)$. And among employees reporting they were not covered by Social Security, 78.1 percent $=699 / 895$ (80.8 percent $=193 / 239)$ reported having a pension on their job. Of 2,649 (762) respondents who reported either being a government worker or a noncovered employee, 84.4 percent $=2,235 / 2,649(87.7$ percent $=668 / 762)$ reported having a pension in that employment.

W2 data report the number of employees with non-FICA earnings. Column 4 indicates the numbers of respondents who, according to the W2 data, were employees on non-FICA jobs. Column 5 sums columns 3 and 4, indicating the number of respondents who either self-reported they held jobs that were not covered by FICA, or who has an attached report from the Social Security Administration indicating they had held a job that was not covered by FICA. Altogether, that provides a sample from the original HRS cohort of 1,064 (266) respondents who ever held a job that was not covered by Social Security. Of those, 858 (218) had a pension.

One might also be concerned about errors introduced when matching jobs between the first wave and the third wave of the HRS where we take information about the respondent's noncovered jobs. To address this concern, row 1 of Table 4 presents comparable data from 2006, where respondents were asked about government employment and coverage by FICA in the same wave of the HRS. Of 5,089 current employees, 23.4 percent $(1,191 / 5,089)$ reported they were government employees, and 23.2 percent $(1,183 / 5,089)$ either self-reported or were reported in their W2 as not covered by Social Security. Once again, however, there is only limited overlap between those reporting being a government worker and those reporting they were not covered by Social Security. Using the same methodology as above, 81.7 percent $(966 / 1,183)$ of employees who reported having a current job that was not covered by Social Security did not report working for the government. The problem again seems to be too few respondents identifying themselves as government employees. Of government workers, 18.2 percent $(217 / 1,191)$ reported being not covered by Social Security. 
Table 3: Number of Employees by Pension Status, Government Employment, and by Social Security Coverage for Current, Last, and Previous Jobs: HRS Cohort Household Ages 51 to 61 in 1992; Early Boomer Cohort Ages 51 to 56 in 2004

\begin{tabular}{|l|c|c|c|c|c|c|}
\hline & $\begin{array}{l}\text { Number of } \\
\text { Employees }\end{array}$ & $\begin{array}{l}\text { Government } \\
\text { Employees }\end{array}$ & $\begin{array}{l}\text { Non-Covered } \\
\text { Employees } \\
\text { (self-report) }\end{array}$ & $\begin{array}{l}\text { Non-FICA } \\
\text { Employees } \\
\text { (W2 data) }\end{array}$ & $\begin{array}{l}\text { Non-covered } \\
\text { (self-report or } \\
\text { W2) }\end{array}$ & $\begin{array}{l}\text { Government or } \\
\text { Non-Covered } \\
\text { Employees }\end{array}$ \\
\hline $\begin{array}{l}\text { HRS } \\
\text { All Jobs } \\
\text { with } \\
\text { Pensions }\end{array}$ & 7480 & 1914 & 699 & 256 & $\begin{array}{c}858 \\
(858 / 2235)=.38\end{array}$ & 2235 \\
\hline $\begin{array}{l}\text { HRS All } \\
\text { jobs }\end{array}$ & 10703 & 2168 & 895 & 269 & $\begin{array}{c}1064 \\
(1064 / 2649)=.40\end{array}$ & 2649 \\
\hline $\begin{array}{l}\text { Early } \\
\text { Boomers } \\
\text { All Jobs } \\
\text { with } \\
\text { Pensions }\end{array}$ & 2241 & 607 & 193 & 48 & $\begin{array}{c}218 \\
(218 / 668)=.33\end{array}$ & 668 \\
\hline $\begin{array}{l}\text { Early } \\
\text { Boomers } \\
\text { All jobs }\end{array}$ & 2906 & 681 & 239 & 54 & $\begin{array}{r}266 \\
(266 / 762)=.35\end{array}$ & 762 \\
\hline
\end{tabular}

A margin of plus or minus 3 years is used for matching those who reported start and end dates or number of years working.

We do not know if an R was government/non-covered at a job started after 1992. We know the answer to that question only if $\mathrm{s} / \mathrm{he}$ had the same job in 2004 where s/he was asked if the job is a FICA job or in 2006 if s/he reported working for a federal or state government. 
Table 4: Number of Government and Non-Covered Employees from Current Job in 2006

\begin{tabular}{|l|c|c|c|c||}
\hline & $\begin{array}{c}\text { Number of } \\
\text { Employees }\end{array}$ & $\begin{array}{c}\text { Number of } \\
\text { Government } \\
\text { Employees }\end{array}$ & $\begin{array}{c}\text { Number of Non- } \\
\text { Covered } \\
\text { Employees* }\end{array}$ & $\begin{array}{c}\text { Government } \\
\text { and/or Non- } \\
\text { Covered } \\
\text { Employees }\end{array}$ \\
\hline \hline $\begin{array}{l}\text { Respondents in } \\
2006\end{array}$ & 5,089 & 1,191 & 1,183 & 2,157 \\
\hline $\begin{array}{l}\text { Respondents in } \\
\text { Also Cov Who Were } \\
\text { a Pension }\end{array}$ & 2,698 & 866 & 219 & 922 \\
\hline \hline
\end{tabular}

*Non-FICA information is included. 
Row 2 of Table 4 limits the sample from row 1 to those with a pension who also reported a positive value for the pension, narrowing the population in our search for those who are subject to WEP. As expected, the share of employees who are government workers is higher among those who had a pension on their current job (866/2698 = 32 percent vs. 23 percent in row 1).

Table 4 tells us two things. First, it strengthens the evidence that the very small overlap between respondents who say they are government workers and those who say their job is not covered by Social Security is the result of a failure of some respondents to recognize that they are government employees. Second, by narrowing the population to those who worked in government or non-covered current jobs and earned a pension on those jobs, we come closer to the population subject to WEP and GPO.

\section{Individuals and Households Subject to WEP and GPO}

The next step is to isolate those individuals and households where a respondent worked in a job covered by Social Security, worked in a job not covered by Social Security, whether in a current job or in a job held in the past, and earned a pension on the uncovered job. Table 5 focuses on individuals who meet these qualifications, while Table 6 focuses on households.

We begin with the data in Table 5. Results are reported for the original HRS cohort, those 51 to 61 in 1992, and for the Early Boomers, those 51 to 56 in 2004. The HRS cohort is over four times the size of the Early Boomers, so we will concentrate on those results while also noting the results for the Early Boomers in parentheses.

The numbers in this table indicate the basic affected populations in this study. From row 1, column 2, 548 respondents from the original HRS cohort (and 127 from the Early Boomers) reported they held a job not covered by Social Security, where they also were covered by a pension. This group is potentially subject to GPO. Row 1, column 3 then isolates the respondents subject to WEP by restricting the group to those who also earned Social Security benefits by also working on a covered job. Of those with non-covered employment (either reported in the selfreport or found in the W2 data), who also have a pension from that job, 72 percent of the original cohort members (397/548) and 69 percent of the Early Boomers (88/127) are entitled to Social Security benefits. Turning to the importance of the affected population relative to all government workers or to all employed, of 10,585 respondents in 1992, 26 percent worked in a government or non-covered job, with a comparable percentage of Early Boomers (761/2,901) working in government or non-covered jobs. From column 1, 1,105 members of the original HRS cohort 
reported ever working in a non-covered job. Those subject to WEP constitute about 3.8 percent of all former employees (397/10,585). The comparable figure for the Early Boomer cohort is 3.0 percent $(88 / 2,901)$.

For data at the household level, we turn to Table 6. Once again, we begin with the 1992 cohort. Of 7,623 households, 292, or 3.8 percent are subject to either WEP or to GPO. The comparable figure for the Early Boomer cohort is 3.5 percent $(75 / 2,150)$. Forty eight percent $(141 / 292)$ of the households from the original HRS cohort subject to either WEP or GPO are subject to both. The figure is 36 percent (27/75) for the Early Boomer cohort.

\section{Effects of WEP and GPO on Social Security Benefits and in Relation to Wealth}

Having examined the numbers of affected respondents and respondent households, we now calculate the basic values of Social Security benefits with and without WEP and GPO adjustments. These calculations follow the formulas presented in Table 1 for each of the scenarios based on different work histories.

Social Security benefits from covered employment are calculated by taking the covered earnings history and plugging that into ANYPIA, software provided by the Social Security Administration. ANYPIA also asks for the expected date of claiming. For those who also worked in uncovered employment, ANYPIA asks about the value of any pension earned. If no pension was earned on the uncovered job, there is no adjustment due to WEP. If a pension was earned, the WEP adjustment is calculated by the ANYPIA program, which limits the WEP adjustment to half the value of the uncovered pension. The benefits paid to the spouse of a person who is subject to WEP are reduced to half the WEP adjusted benefit of the primary earner, with further adjustment for age of retirement. Survivor benefits are not adjusted for WEP. The GPO adjustment is calculated by subtracting two thirds of the value of the pension from uncovered work from the spouse or survivor benefits of the person who worked and earned a pension in uncovered employment. 
Table 5: Number of Respondents with Non-Covered Jobs That Included a Pension, Who Are Also Entitled to Social Security Benefits from Covered Employment

\begin{tabular}{|l|c|c|c|c|c|}
\hline & $\begin{array}{c}\text { Number Ever } \\
\text { Reporting Non- } \\
\text { covered Job }\end{array}$ & $\begin{array}{c}\text { Number Reporting } \\
\text { Non-covered Job } \\
\text { with Pension } \\
\text { (potentially subject } \\
\text { to GPO) }\end{array}$ & $\begin{array}{c}\text { Number Reporting } \\
\text { Non-covered Job } \\
\text { with Pension and } \\
\text { Covered Job } \\
\text { Having Earned } \\
\text { Social Security } \\
\text { Entitlement } \\
\text { (subject to WEP) }\end{array}$ & $\begin{array}{c}\text { Total } \\
\text { Government or } \\
\text { Employees }\end{array}$ & Total Employees \\
\hline HRS cohort in & 1,105 & 548 & 397 & 2,758 & 10,585 \\
\hline EBs in 2004 & 266 & 127 & 88 & 761 & 2,901 \\
\hline
\end{tabular}


Table 6: Number of Households Subject to WEP and GPO

\begin{tabular}{|l|c|c|c|c|c|}
\hline & $\begin{array}{c}\text { Households with At } \\
\text { Least One Worker } \\
\text { Affected by WEP }\end{array}$ & $\begin{array}{c}\text { Households with } \\
\text { At Least One } \\
\text { Worker } \\
\text { Affected by } \\
\text { GPO }\end{array}$ & $\begin{array}{c}\text { Households with } \\
\text { At Least One } \\
\text { Worker Affected } \\
\text { by WEP or GPO }\end{array}$ & $\begin{array}{c}\text { Households } \\
\text { Affected by } \\
\text { Both WEP and } \\
\text { GPO }\end{array}$ & $\begin{array}{c}\text { Total } \\
\text { Households }\end{array}$ \\
\hline \hline $\begin{array}{l}\text { HRS cohort in } \\
1992\end{array}$ & 282 & 151 & 292 & 141 & 7,623 \\
\hline EBs in 2004 & 75 & 28 & 75 & 27 & 2,150 \\
\hline
\end{tabular}


Pension plans are central to the WEP and GPO calculations. They are valued using respondent reports of expected benefits for defined benefit plans, or of plan balances for those with defined contribution plans. We then determine whether former public sector employees who also earned Social Security benefits should have a WEP or GPO offset to those benefits. For purposes of determining WEP and GPO offsets, pensions are valued on a monthly basis. Defined benefit plan values are derived from respondent reports of expected monthly pension benefits, monthly pension receipt if in pay status, monthly annuity, IRA balances from rolled over DB or DC plans, and lump sum payouts. Defined contribution plan values are based on respondent reports of account values, including rollovers and lump sums. A monthly benefit is computed for DC plans and other balances using a table provided by the Social Security Administration. These benefits also take account of the date that Social Security benefits are first received.

In sum, we use three different key dates: zero earnings are projected for all years after the date an individual left the labor force; otherwise we use the date when respondents in the selfreported retirement sequence said they expect to stop working (or 62 if that was missing, or 70 if the expectation was working past 70). For the expected date of claiming Social Security benefits, we use the respondent's self-report of when (s)he expects to receive Social Security benefits; again using 62 if missing and 70 for 70 and over. We assume the date of receipt of pension benefits corresponds to the date of receipt of Social Security benefits. For those who already started receiving Social Security benefits when first asked, we assume they started receiving benefits at age 62. With these assumptions, we may miss some of the gaming by sophisticated claimants. However, we do not count any pension received against WEP if the payments are observed before the expected Social Security claiming age, so someone who claimed the pension early and did not expect to claim Social Security until later is allowed to game the system.

To set the stage, Table 7 reports the present values of Social Security benefits with and without WEP adjustments and the present values of pensions from covered and from uncovered employment, all at the respondent level. These calculations are made for a number of different populations classified by their employment history in covered and uncovered work. The present values of Social Security and pension benefits for members of both the original HRS cohort and the Early Boomer cohort are reported in 1992 dollars. 
As seen in column 1, among the 1,105 respondents in the original HRS cohort who ever reported a non-covered job, WEP and GPO offsets reduce Social Security wealth from \$76,828 to $\$ 71,599$, or by 6.8 percent. The comparable reduction for the Early Boomer cohort in rows 5 and 6 if column 1 is 7.2 percent $(75,844 / 81,686)$. From column 2, for the 548 HRS cohort respondents who worked in non-covered jobs offering a pension, and thus were potentially subject to GPO, WEP and GPO adjustments average 13.0 percent $(64,179 / 73,810)$. For the Early Boomers, the reduction is 14.3 percent $(72,455 / 84,541)$. Turning to column 3 , within the HRS cohort, those having worked in a noncovered job offering a pension, while also earning Social Security benefits in other employment, and thus who are subject to WEP, have their benefits reduced by WEP and GPO adjustments by an average of 14.3 percent $(71,788 / 83,804)$.The comparable reduction within the Early Boomer cohort is 15.2 percent $(77,949 / 91,870)$.

Among those who worked in uncovered employment, the pensions earned from uncovered work were substantially higher than the pensions from work on jobs covered by Social Security. Part of the reason is that when a job was not covered by Social Security, the pension benefit was designed to make up for the shortfall. From row 3, column 1, pension wealth from uncovered work is $\$ 84,339$ for members of the original HRS cohort who ever worked in uncovered employment, while from row 4, column 1, it is $\$ 29,195$ from work in covered employment. Within the Early Boomer cohort, the comparable figures are \$85,846 and \$14,926. Among those members of the original HRS cohort who held an uncovered job that also offered a pension, the pension from uncovered work is worth $\$ 160,460$ (row 3, column 2). This is almost twice the value of Social Security for all employees (\$87,686 in row 1, column 5). The comparable ratio for the Early Boomer cohort is roughly 1.4 to $1(148,948 / 105,608)$.

All told, those in the original HRS cohort who ever worked in an uncovered job earned a total of \$185,133 in present value from Social Security after adjustment for WEP and GPO plus pensions from uncovered and from covered employment $(71,599+84,339+29,195$, from column 1, rows 2, 3 and 4). In comparison, government employees who always worked in covered employment had almost identical pensions and Social Security, worth \$182,994 (89,072 + 93,922 in column 4, rows 1 and 4). Comparable numbers from the Early Boomer cohort also suggest that pension values plus Social Security are slightly lower for those who ever worked in an uncovered job, \$176,616 (75,844 + 85,846 + 14,926), compared to government employees who always worked in covered employment, \$197,986 $(109,218+88,768)$. 
Table 7: Values of Social Security Benefits Before and After WEP and GPO Adjustments and Values of Pensions from Uncovered and Covered Employment, at the Respondent Level (All Values Are in 1992 Dollars)

\begin{tabular}{|c|c|c|c|c|c|c|}
\hline & & $\begin{array}{c}\text { Among Those } \\
\text { Ever } \\
\text { Reporting } \\
\text { Non-covered } \\
\text { Job }\end{array}$ & $\begin{array}{l}\text { Among Those } \\
\text { Reporting Non- } \\
\text { covered Job } \\
\text { with Pension } \\
\text { (potentially } \\
\text { subject to GPO) }\end{array}$ & $\begin{array}{c}\text { Among Those } \\
\text { Reporting Non-covered } \\
\text { Job with Pension and } \\
\text { Covered Job Having } \\
\text { Earned Social Security } \\
\text { Entitlement (subject to } \\
\text { WEP) }\end{array}$ & $\begin{array}{c}\text { Among } \\
\text { Government } \\
\text { Employees Who } \\
\text { Always Worked } \\
\text { in Covered } \\
\text { Employment }\end{array}$ & $\begin{array}{l}\text { Among Total } \\
\text { Employees Who } \\
\text { Always Worked } \\
\text { in Covered } \\
\text { Employment }\end{array}$ \\
\hline \multirow[t]{4}{*}{$\begin{array}{l}\text { HRS } \\
\text { cohort in } \\
1992\end{array}$} & $\begin{array}{l}\text { Value of Social Security } \\
\text { Benefits not Adjusted for } \\
\text { WEP or GPO }\end{array}$ & $\begin{array}{l}76,828 \\
(1105)\end{array}$ & $\begin{array}{l}73,810 \\
(548)\end{array}$ & $\begin{array}{c}83,804 \\
(397)\end{array}$ & $\begin{array}{l}89,072 \\
(1551)\end{array}$ & $\begin{array}{l}87,686 \\
(9452)\end{array}$ \\
\hline & $\begin{array}{l}\text { Value of Social Security } \\
\text { Benefits after adjustment for } \\
\text { WEP and GPO }\end{array}$ & 71,599 & 64,179 & 71,788 & - & - \\
\hline & $\begin{array}{l}\text { Value of Pension from } \\
\text { Uncovered Employment }\end{array}$ & 84,339 & 160,460 & 136,551 & - & - \\
\hline & $\begin{array}{l}\text { Value of Pension from } \\
\text { Covered Employment }\end{array}$ & 29,195 & 15,195 & 20,622 & 93,922 & 59,438 \\
\hline \multirow[t]{4}{*}{$\begin{array}{l}\text { Early } \\
\text { Boomers } \\
\text { in } 2004\end{array}$} & $\begin{array}{l}\text { Value of Social Security } \\
\text { Benefits not Adjusted for } \\
\text { WEP or GPO }\end{array}$ & $\begin{array}{l}81,686 \\
(266)\end{array}$ & $\begin{array}{c}84,541 \\
(127)\end{array}$ & $\begin{array}{c}91,870 \\
(92)\end{array}$ & $\begin{array}{c}109,218 \\
(495)\end{array}$ & $\begin{array}{c}105,608 \\
(2636)\end{array}$ \\
\hline & $\begin{array}{l}\text { Value of Social Security } \\
\text { Benefits after adjustment for } \\
\text { WEP and GPO }\end{array}$ & 75,844 & 72,455 & 77,949 & - & - \\
\hline & $\begin{array}{l}\text { Value of Pension from } \\
\text { Uncovered Employment }\end{array}$ & 85,846 & 148,948 & 132,752 & - & - \\
\hline & $\begin{array}{l}\text { Value of Pension from } \\
\text { Covered Employment }\end{array}$ & 14,926 & 8,779 & 9,95 & 88,768 & 55,020 \\
\hline
\end{tabular}


Table 8 provides a further break down of WEP and GPO adjustments among various respondent groups. Column heads report the population groups according how their benefits are affected by WEP and GPO, and for comparison, for all government or non-covered employees, and among all employees.

In Table 8 we define WEP adjustments as the reduction in benefits due to the WEP adjustment alone. The GPO adjustment is calculated as the total effect of reducing benefits to account for both WEP and GPO, less the value of the WEP adjustment. WEP and GPO adjustments for the relevant population groups are reported in rows 1 and 2 of Table 8. Values of Social Security benefits before and after the adjustments are reported in the next three rows, with the ratios of adjusted to unadjusted Social Security values reported in rows 5 and 6 of each panel.

Once we disaggregate, care is required in making comparisons between the original HRS sample, with over fifty observations in even the smallest cell, and the Early Boomer cohort, where the number of observations falls to 16 for those subject to both WEP and GPO.

Looking across row 1 for the original HRS cohort, the largest WEP adjustment is in column 1, \$16,427 for the 269 respondents who are affected by WEP alone. For the Early Boomers, the largest WEP adjustment is found in row 8, column 3, which includes those affected by WEP and GPO. There are only 16 observations in that cell, however. Looking across row 2, the largest GPO adjustment of $\$ 41,531$ falls on the 85 respondents who are subject to WEP and GPO. That is, their benefits are reduced by GPO by $\$ 41,531$ above and beyond the $\$ 6,583$ reduction in their benefits due to WEP alone. Looking at the comparable cell for Early Boomers, once again the largest adjustment, $\$ 16,737$, is for those affected by both WEP and GPO. For the original HRS cohort, the GPO adjustment for those affected only by GPO amounts to $\$ 8,900$. The comparable value for the twelve observations we have for Early Boomers is $\$ 6,151$. 
Table 8: WEP and GPO Adjustments Among Individuals (All Values Are in 1992 Dollars)

\begin{tabular}{|c|c|c|c|c|c|c|c|}
\hline & & $\begin{array}{l}\text { Among Those } \\
\text { Affected by } \\
\text { WEP and not } \\
\text { by GPO }\end{array}$ & $\begin{array}{l}\text { Among Those } \\
\text { Affected by } \\
\text { GPO and not } \\
\text { by WEP }\end{array}$ & $\begin{array}{l}\text { Among Those } \\
\text { Affected by } \\
\text { WEP and } \\
\text { GPO }\end{array}$ & $\begin{array}{l}\text { Among Those } \\
\text { Affected by } \\
\text { WEP or GPO }\end{array}$ & $\begin{array}{l}\text { Among all } \\
\text { Government } \\
\text { or Non- } \\
\text { covered } \\
\text { Employees }\end{array}$ & $\begin{array}{l}\text { Among All } \\
\text { Employees }\end{array}$ \\
\hline \multirow[t]{4}{*}{$\begin{array}{l}\text { HRS cohort } \\
\text { in } 1992\end{array}$} & WEP Adjustment & $\begin{array}{c}16,427 \\
(269)\end{array}$ & 0 & $\begin{array}{c}6,583 \\
(85) \\
\end{array}$ & $\begin{array}{c}11,854 \\
(420)\end{array}$ & $\begin{array}{c}1,768 \\
(2656)\end{array}$ & $\begin{array}{c}460 \\
(10585) \\
\end{array}$ \\
\hline & $\begin{array}{l}\text { Value of Social Security } \\
\text { Benefits After WEP } \\
\text { Adjustments }\end{array}$ & 53,197 & 0 & 53,993 & 55,672 & 82,210 & 86,090 \\
\hline & $\begin{array}{l}\text { Value of Social Security } \\
\text { Benefits After GPO } \\
\text { Adjustments }\end{array}$ & 0 & 59,025 & 12,461 & 45,868 & 81,666 & 85,774 \\
\hline & $\begin{array}{l}\text { Ratio of Adjusted SS } \\
\text { Benefits after GPO to } \\
\text { Unadjusted Value }\end{array}$ & - & 0.87 & 0.21 & 0.68 & 0.97 & 0.99 \\
\hline
\end{tabular}




\begin{tabular}{|l|l|c|c|c|c|c|c|}
\hline & & $\begin{array}{c}\text { Among Those } \\
\text { Affected by } \\
\text { WEP and not } \\
\text { by GPO }\end{array}$ & $\begin{array}{c}\text { Among Those } \\
\text { Affected by } \\
\text { GPO and not } \\
\text { by WEP }\end{array}$ & $\begin{array}{c}\text { Among Those } \\
\text { Affected by } \\
\text { WEP and } \\
\text { GPO }\end{array}$ & $\begin{array}{c}\text { Among Those } \\
\text { Affected by } \\
\text { WEP or GPO }\end{array}$ & $\begin{array}{c}\text { Among all } \\
\text { Government } \\
\text { or Non- } \\
\text { covered } \\
\text { Employees }\end{array}$ & $\begin{array}{c}\text { Among All } \\
\text { Employees }\end{array}$ \\
\hline $\begin{array}{l}\text { Early } \\
\text { Boomers in } \\
2004\end{array}$ & WEP Adjustment & $\begin{array}{c}16,209 \\
(77)\end{array}$ & 0 & $\begin{array}{c}28,401 \\
(16)\end{array}$ & $\begin{array}{c}16,214 \\
(105)\end{array}$ & $\begin{array}{c}1,873 \\
(761)\end{array}$ & $\begin{array}{c}575 \\
(2901)\end{array}$ \\
\cline { 2 - 8 } & GPO Adjustment & 0 & 6,151 \\
$(12)$ & 16,737 & 3,253 & 194 & 112 \\
\cline { 2 - 8 } & $\begin{array}{l}\text { Value of Social Security } \\
\text { Benefits After WEP } \\
\text { Adjustments }\end{array}$ & 67,812 & - & 38,409 & 65,120 & 97,721 & 102,856 \\
\cline { 2 - 8 } & $\begin{array}{l}\text { Value of Social Security } \\
\text { Benefits After GPO } \\
\text { Adjustments }\end{array}$ & - & 77,303 & 21,672 & 61,866 & 97,527 & 102,743 \\
\cline { 2 - 8 } & $\begin{array}{l}\text { Value of Social Security } \\
\text { Benefits Without } \\
\text { Adjustments }\end{array}$ & 84,022 & 83,454 & 66,810 & 81,334 & 99,594 & 103,431 \\
\cline { 2 - 8 } & $\begin{array}{l}\text { Ratio of Adjusted SS } \\
\text { Benefits after WEP to } \\
\text { Unadjusted Value }\end{array}$ & 0.81 & - & 0.57 & 0.80 & 0.98 & 0.99 \\
\cline { 2 - 8 } & $\begin{array}{l}\text { Ratio of Adjusted SS } \\
\text { Benefits after GPO to } \\
\text { Unadjusted Value }\end{array}$ & - & 0.93 & 0.32 & 0.76 & 0.98 & 0.99 \\
\hline
\end{tabular}


Among the population of 420 respondents to the original HRS cohort affected by either WEP or GPO, comparing rows 1 and 2, column 4, the WEP adjustment is $\$ 11,854$ and the GPO adjustment is another $\$ 9,804$. Together these adjustments reduce the present value of Social Security benefits by 32.1 percent $(45,868 / 67,526)$ among the affected population. The comparable figures for the 105 respondents in this cell for the Early Boomer cohort, the value of Social Security benefits are reduced by 23.9 percent $(61,866 / 81,334)$. Among all government or non-covered employees, in the original HRS cohort, WEP and GPO together reduce benefits by 2.8 percent $(81,666 / 83,978)$, and among all employees, by 0.9 percent $(85,774 / 86,550)$. In the Early Boomer cohort, WEP and GPO together reduce benefits by 2.1 percent $(97,527 / 99,594)$, and among all employees, by 0.7 percent $(102,743 / 103,431)$.

Table 9 reports these same values for households. Once again, in some disaggregated categories the cell sizes for the Early Boomer cohort are sometimes quite small. In row 1, the largest WEP adjustment is in column 3, $\$ 17,812$ for the 141 HRS cohort households affected by both WEP and GPO. There is only a slightly smaller WEP adjustment $(\$ 17,496)$ among those households affected by WEP and not GPO. There are similar results within the Early Boomer cohort, where the largest WEP adjustment is for the 27 households affected by both WEP and GPO. Looking across row 2, for the original HRS cohort, the largest GPO adjustment of \$28,805 again falls on the 141 households subject to WEP and GPO. That is, their benefits are reduced by GPO by $\$ 28,805$ above and beyond the $\$ 17,812$ reduction in their benefits due to WEP alone. Similarly, the largest GPO adjustments for the Early Boomers are in the 27 households affected by both WEP and GPO, at $\$ 12,589$. The GPO adjustment for those HRS households affected only by GPO amounts to $\$ 5,612$, while there is only one household falling in that category in the Early Boomer cohort. 
Table 9: WEP and GPO Adjustments Among Households (All Values Are in 1992 Dollars)

\begin{tabular}{|c|c|c|c|c|c|c|c|}
\hline & & $\begin{array}{c}\text { Among } \\
\text { Those } \\
\text { Affected by } \\
\text { WEP and Not } \\
\text { by GPO }\end{array}$ & $\begin{array}{c}\text { Among } \\
\text { Those } \\
\text { Affected by } \\
\text { GPO and not } \\
\text { by WEP }\end{array}$ & $\begin{array}{l}\text { Among } \\
\text { Those } \\
\text { Affected by } \\
\text { WEP and } \\
\text { GPO }\end{array}$ & $\begin{array}{l}\text { Among } \\
\text { Those } \\
\text { Affected by } \\
\text { WEP or } \\
\text { GPO }\end{array}$ & $\begin{array}{l}\text { Among All } \\
\text { Government } \\
\text { or Non- } \\
\text { covered } \\
\text { Employees }\end{array}$ & $\begin{array}{l}\text { Among All } \\
\text { Employees }\end{array}$ \\
\hline \multirow{7}{*}{$\begin{array}{l}\text { HRS } \\
\text { Households } \\
\text { in } 1992\end{array}$} & WEP Adjustment & $\begin{array}{c}17,496 \\
(141)\end{array}$ & 0 & $\begin{array}{c}17,812 \\
(141)\end{array}$ & $\begin{array}{c}17,050 \\
(292)\end{array}$ & $\begin{array}{c}2,109 \\
(2337)\end{array}$ & $\begin{array}{c}704 \\
(7051)\end{array}$ \\
\hline & GPO Adjustment & 0 & $\begin{array}{c}5,612 \\
(10)\end{array}$ & 28,805 & 14,101 & 1,600 & 569 \\
\hline & $\begin{array}{l}\text { Value of Social } \\
\text { Security Benefits } \\
\text { After WEP } \\
\text { Adjustments } \\
\end{array}$ & 125,181 & 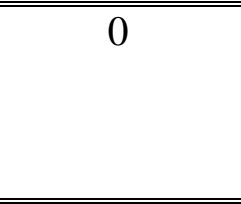 & 102,331 & 112,337 & 144,631 & 136,427 \\
\hline & $\begin{array}{l}\text { Value of Social } \\
\text { Security Benefits } \\
\text { After GPO } \\
\text { Adjustments } \\
\end{array}$ & 0 & 66,698 & 73,526 & 98,235 & 143,032 & 135,858 \\
\hline & $\begin{array}{l}\text { Value of Social } \\
\text { Security Benefits } \\
\text { Without } \\
\text { Adjustments } \\
\end{array}$ & 142,677 & 72,310 & 120,143 & 129,386 & 146,740 & 137,130 \\
\hline & $\begin{array}{l}\text { Ratio of Adjusted SS } \\
\text { Benefits after WEP } \\
\text { to Unadjusted Value }\end{array}$ & 0.88 & $\overline{-1}$ & 0.85 & 0.86 & 0.99 & 0.99 \\
\hline & $\begin{array}{l}\text { Ratio of Adjusted SS } \\
\text { Benefits after GPO } \\
\text { to Unadjusted Value }\end{array}$ & - & 0.93 & 0.61 & 0.76 & 0.98 & 0.99 \\
\hline
\end{tabular}




\begin{tabular}{|c|c|c|c|c|c|c|c|}
\hline & & $\begin{array}{c}\text { Among } \\
\text { Those } \\
\text { Affected by } \\
\text { WEP and Not } \\
\text { by GPO }\end{array}$ & $\begin{array}{l}\text { Among } \\
\text { Those } \\
\text { Affected by } \\
\text { GPO and not } \\
\text { by WEP }\end{array}$ & $\begin{array}{l}\text { Among } \\
\text { Those } \\
\text { Affected by } \\
\text { WEP and } \\
\text { GPO }\end{array}$ & $\begin{array}{l}\text { Among } \\
\text { Those } \\
\text { Affected by } \\
\text { WEP or } \\
\text { GPO }\end{array}$ & $\begin{array}{l}\text { Among All } \\
\text { Government } \\
\text { or Non- } \\
\text { covered } \\
\text { Employees }\end{array}$ & $\begin{array}{l}\text { Among All } \\
\text { Employees }\end{array}$ \\
\hline \multirow{7}{*}{$\begin{array}{l}\text { Early } \\
\text { Boomers in } \\
2004\end{array}$} & WEP Adjustment & $\begin{array}{c}16,133 \\
(48) \\
\end{array}$ & 0 & $\begin{array}{c}34,375 \\
(27) \\
\end{array}$ & $\begin{array}{c}22,402 \\
(76) \\
\end{array}$ & $\begin{array}{l}2,579 \\
(660) \\
\end{array}$ & $\begin{array}{c}851 \\
(2001) \\
\end{array}$ \\
\hline & GPO Adjustment & 0 & $\begin{array}{c}1,708 \\
(1)\end{array}$ & 12,589 & 4,495 & 518 & 171 \\
\hline & $\begin{array}{l}\text { Value of Social } \\
\text { Security Benefits } \\
\text { After WEP } \\
\text { Adjustments }\end{array}$ & 120,423 & - & 129,277 & 123,252 & 169,602 & 160,454 \\
\hline & $\begin{array}{l}\text { Value of Social } \\
\text { Security Benefits } \\
\text { After GPO } \\
\text { Adjustments }\end{array}$ & - & 94,689 & 116,689 & 118,757 & 169,085 & 160,283 \\
\hline & $\begin{array}{l}\text { Value of Social } \\
\text { Security Benefits } \\
\text { Without } \\
\text { Adjustments } \\
\end{array}$ & 136,556 & 96,398 & 163,653 & 145,654 & 172,182 & 161,305 \\
\hline & $\begin{array}{l}\text { Ratio of Adjusted SS } \\
\text { Benefits after WEP } \\
\text { to Unadjusted Value }\end{array}$ & 0.88 & - & 0.79 & 0.85 & 0.99 & 0.99 \\
\hline & $\begin{array}{l}\text { Ratio of Adjusted SS } \\
\text { Benefits after GPO } \\
\text { to Unadjusted Value }\end{array}$ & - & 0.98 & 0.71 & 0.82 & 0.98 & 0.99 \\
\hline
\end{tabular}

*Households have at least one member affected. 
Comparing rows 1 and 2, column 4, among the 292 HRS households affected by either WEP or GPO, the WEP adjustment is $\$ 17,050$ and the GPO adjustment is another $\$ 14,101$, reducing the present value of Social Security benefits by 24.1 percent among the affected households (98,235/129,386). For the Early Boomer cohort, among the 76 HRS households affected by either WEP or GPO, the WEP adjustment is $\$ 22,402$ and the GPO adjustment is another $\$ 4,495$, reducing the present value of Social Security benefits by 18.5 percent $(118,757 / 145,654)$. Among households with at least one government or non-covered employee, in the HRS cohort, WEP and GPO together reduce benefits by 2.5 percent $(143,032 / 146,740)$, and among all households with at least one past or current employee, by 0.9 percent $(135,858 / 137,130)$. The comparable figures for the Early Boomer cohort are 1.8 percent $(169,085 / 172,182)$ and 0.6 percent $(160,283 / 161,305)$.

Table 10 relates the present values of the Social Security and pension benefits, and the WEP and GPO adjustments, to the household's total wealth. ${ }^{14}$ From column 1, row 4, households from the original HRS cohort affected by the WEP adjustment lose $\$ 17,496(142,677$ - 125,181), or 12.3 percent of their benefits. The comparable group of Early Boomers loses 11.7 percent of their benefits $(15,920 / 136,603)$. As seen in column 2, households from the HRS cohort affected by GPO and not by WEP lose $\$ 5,612(72,309-66,697)$, or 7.8 percent of the present value of their benefits. Those from the Early Boomer cohort affected by GPO only lose $\$ 1,709$, or 1.8 percent of their basic benefit. By far the largest impact is on households affected by both WEP and GPO. Those from the original HRS cohort lose $\$ 45,786(117,764$ - 71,978) in present value of benefits, or 38.9 percent of their total Social Security benefits. Those subject to WEP and GPO from the Early Boomer cohort lose 28.7 percent of their benefit (46,964/163,653). Taking these households together in column 4, those from the HRS cohort affected by either WEP or GPO lose $\$ 30,596(128,348-97,752)$, or 23.8 percent of their total Social Security benefits.

${ }^{14}$ Note that there is a slight difference between Tables 9 and 10. Because we are dealing with total wealth in Table 10, we have trimmed the observations to eliminate those in the top and bottom 1 percent of wealth holding households. Table 9 includes those households. 
Members from the Early Boomer cohort lose 18.5 percent of their basic benefit $(26,907 / 145,805)$.

These benefit losses are small compared to the public pensions received, which range from $\$ 143,000$ and $\$ 167,000$ for members of the original HRS cohort, and from $\$ 135,000$ to $\$ 150,000$ for the three groups of Early Boomers where there are at least 25 observations. For members of the original HRS cohort affected by WEP or GPO, the umbrella group, benefits lost amount to ten percent of the value of pensions plus Social Security they in fact receive $(30,596 / 305,478)$ and to 6.1 percent of their total wealth $(30,596 / 497,635)$. Comparable losses for members of the Early Boomer cohort amount to 8.7 percent $(26,907 / 310,086)$ of total Social Security plus pension wealth and 5.3 percent of total wealth $(26,907 / 507,113)$.

Among all government or non-covered employees in the original HRS sample, or all employees, these losses represent a much smaller fraction of total wealth, amounting to eight tenths of one percent of wealth for government employees $(3,654 / 472,777)$ and three tenths of one percent of total wealth for the all employees $(1,257 / 402,959)$. Comparable losses from members of the Early Boomer cohort are six tenths of one percent and two tenths of one percent respectively. 
Table 10: Total Wealth, Social Security Wealth with and without Adjustments for WEP and GPO, and Pension Wealth Among Households

\begin{tabular}{|c|c|c|c|c|c|c|c|}
\hline & & $\begin{array}{c}\text { Affected by } \\
\text { WEP and Not } \\
\text { by GPO }\end{array}$ & $\begin{array}{l}\text { Affected by } \\
\text { GPO and not } \\
\text { by WEP }\end{array}$ & $\begin{array}{l}\text { Affected by } \\
\text { WEP and } \\
\text { GPO }\end{array}$ & $\begin{array}{l}\text { Affected by } \\
\text { WEP or } \\
\text { GPO }\end{array}$ & $\begin{array}{l}\text { All Gov't or } \\
\text { Non-covered } \\
\text { Employees }\end{array}$ & $\begin{array}{c}\text { All } \\
\text { Employees }\end{array}$ \\
\hline \multirow[t]{6}{*}{$\begin{array}{l}\text { Households } \\
\text { in } 1992\end{array}$} & $\begin{array}{c}\text { Value of Social Security } \\
\text { Benefits With WEP } \\
\text { Adjustments }\end{array}$ & $\begin{array}{c}125,181 \\
(141)\end{array}$ & - & $\begin{array}{l}99,823 \\
(138)\end{array}$ & $\begin{array}{l}111,243 \\
(289)\end{array}$ & $\begin{array}{c}144,336 \\
(2313)\end{array}$ & $\begin{array}{c}136,750 \\
(6938)\end{array}$ \\
\hline & $\begin{array}{c}\text { Value of Social Security } \\
\text { Benefits With GPO } \\
\text { Adjustments }\end{array}$ & - & $\begin{array}{l}66,697 \\
(10)\end{array}$ & 71,978 & 97,752 & 142,797 & 136,204 \\
\hline & $\begin{array}{l}\text { Reduction in Benefits } \\
\text { from WEP or GPO }\end{array}$ & 17,496 & 5,612 & 45,786 & 30,596 & 3,654 & 1,257 \\
\hline & Value of Public Pension & 143,525 & 160,732 & 167,149 & 155,401 & 39,939 & 13,568 \\
\hline & $\begin{array}{c}\text { Total Value of Social } \\
\text { Security* Plus All } \\
\text { Pensions }\end{array}$ & 326,406 & 388,162 & 278,670 & 305,478 & 288,161 & 233,124 \\
\hline & Total Wealth & 515,356 & 556,357 & 475,274 & 497,635 & 472,777 & 402,959 \\
\hline
\end{tabular}




\begin{tabular}{|c|c|c|c|c|c|c|c|}
\hline & & $\begin{array}{c}\text { Those } \\
\text { Affected by } \\
\text { WEP and Not } \\
\text { by GPO }\end{array}$ & $\begin{array}{l}\text { Those } \\
\text { Affected by } \\
\text { GPO and not } \\
\text { by WEP }\end{array}$ & $\begin{array}{l}\text { Those } \\
\text { Affected by } \\
\text { WEP and } \\
\text { GPO }\end{array}$ & $\begin{array}{l}\text { Those } \\
\text { Affected by } \\
\text { WEP or } \\
\text { GPO }\end{array}$ & $\begin{array}{c}\text { All } \\
\text { Government } \\
\text { or Non- } \\
\text { covered } \\
\text { Employees }\end{array}$ & $\begin{array}{c}\text { All } \\
\text { Employees }\end{array}$ \\
\hline \multirow{5}{*}{$\begin{array}{l}\text { Early } \\
\text { Boomers } \\
\text { Household } \\
\text { in } 2004\end{array}$} & $\begin{array}{c}\text { Value of Social } \\
\text { Security Benefits With } \\
\text { WEP Adjustments }\end{array}$ & $\begin{array}{c}120,683 \\
(47)\end{array}$ & 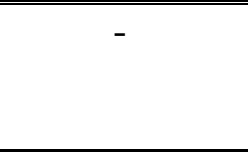 & $\begin{array}{c}129,277 \\
(27)\end{array}$ & $\begin{array}{c}123,453 \\
(75)\end{array}$ & $\begin{array}{c}169,120 \\
(651)\end{array}$ & $\begin{array}{c}160,763 \\
(1965)\end{array}$ \\
\hline & $\begin{array}{c}\text { Value of Social } \\
\text { Security Benefits } \\
\text { Without Adjustments }\end{array}$ & 136,603 & 96,398 & 163,653 & 145,805 & 171,695 & 161,617 \\
\hline & $\begin{array}{l}\text { Reduction in Benefits } \\
\text { from WEP or GPO }\end{array}$ & 15,920 & 1,709 & 46,964 & 26,907 & 3,100 & 1,027 \\
\hline & $\begin{array}{c}\text { Total Value of Social } \\
\text { Security *Plus All } \\
\text { Pensions } \\
\end{array}$ & 323,644 & 95,407 & 294,436 & 310,086 & 295,139 & 244,369 \\
\hline & Total Wealth & 540,319 & 80,115 & 465,124 & 507,113 & 500,670 & 427,431 \\
\hline
\end{tabular}

(All Values Are in 1992 Dollars)

*adjusted benefits after GPO.

Top and bottom 1\% are excluded. 
Table 11 puts the adjustments to Social Security in further perspective by reporting the total wealth for affected households classified according to the structure of the household. Among the households affected by WEP and GPO, in the original HRS cohort as reported in Table 11A, households headed by a single woman have less than half the wealth of households headed by a single man $(194,279 / 410,424)$, with two person households having one third more wealth than those headed by a single man $(549,926 / 410,424)$. There are too few observations in Table 11B to make a similar comparison for the Early Boomers.

Comparing the adjustments in benefits due to WEP or GPO in row 4 with the Social Security wealth of affected households after adjustment in row 3, the adjustments represent a much larger share of Social Security wealth for one person female households. The reduction in benefits amounts to 51.7 percent of basic benefits $(26,345 / 50,937)$ for one person female households compared to 28.5 percent for one person male households $(14,108 / 49,555)$ and 29.9 percent for two person households $(32,227 / 107,865)$. The benefit reduction for one person female households in the Early Boomer Cohort is 28.3 percent of the value of Social Security $(17,376 / 61,405)$, while the reduction is 21.9 percent for couple households $(30,540 / 139,534)$. For the original HRS cohort, these adjustments amount to 13.6 percent $(26,345 / 194,279)$ of the total wealth of single female households, 3.4 percent $(14,108 / 410,424)$ of the total wealth of single male households, and 5.9 percent $(32,227 / 549,926)$ of the total wealth of affected couple households. The comparable reductions for the Early Boomer cohort are 5.5 percent $(17,376 / 318,174)$ for single female households and 5.3 percent for couple households (30,540/576,971). 
Table 11A: Components of Wealth By Household's Work in Uncovered Employment, Social Security Coverage, and Pension from Non-Covered Job, by Household Structure: HRS Cohort in 1992 (All Values Are in 1992 Dollars)

\begin{tabular}{||l|c|c|c|c|c||}
\hline \hline & $\begin{array}{c}\text { One Person } \\
\text { Female } \\
\text { Households } \\
\text { Affected by } \\
\text { WEP or } \\
\text { GPO }\end{array}$ & $\begin{array}{c}\text { One Person } \\
\text { Male } \\
\text { Households } \\
\text { Affected by } \\
\text { WEP or } \\
\text { GPO }\end{array}$ & $\begin{array}{c}\text { Two Person } \\
\text { Households } \\
\text { Affected by } \\
\text { WEP or } \\
\text { GPO }\end{array}$ & $\begin{array}{c}\text { All } \\
\text { Households } \\
\text { Afected by } \\
\text { WEP or } \\
\text { GPO }\end{array}$ & $\begin{array}{c}\text { All } \\
\text { Households }\end{array}$ \\
\hline \hline 1. Total & 194,279 & 410,424 & 549,926 & 497,636 & 395,182 \\
\hline 2. Social Security Plus Pensions & 126,133 & 251,731 & 336,849 & 305,748 & 221,859 \\
\hline 3. Social Security & 50,937 & 49,555 & 107,865 & 97,752 & 130,773 \\
\hline 4. Benefit Reduction from WEP or GPO & 26,345 & 14,108 & 32,227 & 30,596 & 1,183 \\
\hline 5. Pension Value & 75,196 & 202,176 & 228,984 & 207,996 & 91,085 \\
\hline 6. Value of pension from uncovered job & 60,625 & 168,476 & 169,367 & 155,401 & 12,602 \\
\hline 7. Value of pension from covered job & 14,571 & 33,700 & 59,617 & 52,595 & 78,483 \\
\hline 8. Net House Value & 41,381 & 41,600 & 94,344 & 85,008 & 65,36 \\
\hline 9. Real Estate & 2,865 & 49,071 & 32,826 & 29,777 & 24,468 \\
\hline 10. Business Assets & 405 & 14,071 & 5,884 & 5,579 & 19,007 \\
\hline 11. Net Value of Vehicles & 3,874 & 11,357 & 14,931 & 13,342 & 12,224 \\
\hline 12. Financial Assets & 12,715 & 18,450 & 46,762 & 41,032 & 36,934 \\
\hline 13. IRA Assets & 6,905 & 24,142 & 18,329 & 17,148 & 15,329 \\
\hline 14. Observations & 37 & 14 & 238 & 289 & 7470 \\
\hline
\end{tabular}

*The sample excludes the top and bottom 1 percent of wealth holding households. 
Table 11B: Components of Wealth By Household's Work in Uncovered Employment, Social Security Coverage, and Pension from Non-Covered Job, by Household Structure: Early Boomers Cohort in 2004 (All Values Are in 1992 Dollars)

\begin{tabular}{|c|c|c|c|c|c|}
\hline & $\begin{array}{l}\text { One Person } \\
\text { Female } \\
\text { Households } \\
\text { Affected by } \\
\text { WEP or } \\
\text { GPO }\end{array}$ & $\begin{array}{l}\text { One Person } \\
\text { Male } \\
\text { Households } \\
\text { Affected by } \\
\text { WEP or } \\
\text { GPO }\end{array}$ & $\begin{array}{l}\text { Two Person } \\
\text { Households } \\
\text { Affected by } \\
\text { WEP or } \\
\text { GPO }\end{array}$ & $\begin{array}{l}\text { All } \\
\text { Households } \\
\text { Affected by } \\
\text { WEP or } \\
\text { GPO }\end{array}$ & All Households \\
\hline 1. Total & 318,174 & 210,771 & 576,971 & 507,113 & 416,739 \\
\hline 2. Social Security Plus Pensions & 213,825 & 77,545 & 350,047 & 310,086 & 234,215 \\
\hline 3. Social Security & 61,405 & 40,325 & 139,534 & 118,899 & 155,138 \\
\hline 4. Benefit Reduction from WEP or GPO & 17,376 & 9,902 & 30,540 & 26,906 & 958 \\
\hline 5. Pension Value & 152,419 & 37,219 & 210,513 & 191,188 & 79,077 \\
\hline 6. Value of pension from uncovered job & 139,829 & 36,981 & 143,972 & 138,808 & 10,276 \\
\hline 7. Value of pension from covered job & 12,591 & 239 & 66,541 & 52,379 & 68,801 \\
\hline 8. Net House Value & 57,624 & 138,799 & 116,847 & 105,091 & 79,771 \\
\hline 9. Real Estate & 10,095 & 0 & 12,730 & 11,659 & 17,737 \\
\hline 10. Business Assets & 0 & 0 & 17,500 & 13,066 & 14,892 \\
\hline 11. Net Value of Vehicles & 10,118 & 598 & 14,162 & 12,757 & 10,171 \\
\hline 12. Financial Assets & 17,537 & $-6,889$ & 48,164 & 39,428 & 38,931 \\
\hline 13. IRA Assets & 8,974 & 1000 & 17,520 & 15,024 & 21,021 \\
\hline 14. Observations & 16 & 3 & 56 & 75 & 2107 \\
\hline
\end{tabular}

*The sample excludes the top and bottom 1 percent of wealth holding households. 


\section{Disaggregating the Effects on the WEP Adjustment into the Effects of}

\section{Adjusting the Benefit Formula and the Effects of Limiting the Adjustment According to Pension Income}

Some earlier studies used the adjustment in the benefit formula (the replacement rate up to the first bend point) to estimate the size of the WEP adjustment. In their calculations they ignored the limitation on this adjustment to half the value of pensions from uncovered work. Ignoring the limit on the WEP adjustment to half the value of the pension from uncovered work leads the size of the actual WEP adjustment to be overstated by roughly 150 percent.

Table 12 provides the details for this calculation. First, the benefit is calculated without the WEP adjustment. For the original HRS cohort, the present value of Social Security without a WEP adjustment averaged \$76,828 (column 1). With the WEP adjustment, including the limitation of WEP to half the value of the pension from uncovered work, the present value of Social Security benefits is $\$ 72,619$ (column 2). So the actual WEP adjustment for this HRS cohort amounts to $\$ 4,209$ (column 4). Comparable numbers for the Early Boomer cohort are $\$ 81,692$ (column 1) and $\$ 76,892$ (column 2), so the WEP adjustment amounts to $\$ 4,800$ (column 4).

When we assume an artificially large pension, we can isolate the size of the WEP adjustment due only to the change in the reduction in the Social Security replacement rate from 90 percent down to a minimum of 40 percent. This allows us to determine the full effect of the formula change in the absence of any mitigation from the pension on the uncovered job. From column 3, when the WEP reduction is not limited to half the size of the pension, the Social Security benefit for members of the original HRS cohort is reduced to $\$ 66,695$, a total reduction due to the change in the PIA formula of $\$ 10,133$. Thus the limitation of the Social Security benefit to half the size of the pension from uncovered employment reduces the penalty from WEP for members of the original HRS cohort by \$5,924, by 58 percent. For the Early Boomers, the change in the PIA benefit formula alone would reduce benefits by $\$ 12,476$, so consideration of the pension from uncovered work reduces the WEP penalty by $\$ 7,676$, or by 61.5 percent. 
Table 12: Decomposition of WEP Adjustment Among Those Subject to WEP Into Effects of Change in Formula and Limitation on WEP from Pension Offset (All Values Are in 1992 Dollars)

\begin{tabular}{|l|c|c|c|c|c|c|}
\hline & $\begin{array}{c}\text { Social Security } \\
\text { Value Without } \\
\text { WEP } \\
\text { Adjustment }\end{array}$ & $\begin{array}{c}\text { Social Security } \\
\text { Value After } \\
\text { WEP } \\
\text { Adjustment }\end{array}$ & $\begin{array}{c}\text { Social Security } \\
\text { Value Due to } \\
\text { Change in Benefit } \\
\text { Formula }\end{array}$ & $\begin{array}{c}\text { Difference in } \\
\text { Social Security } \\
\text { Value Due to } \\
\text { WEP Adjustment }\end{array}$ & $\begin{array}{c}\text { Difference in } \\
\text { Social Security } \\
\text { Value Due to } \\
\text { Change in } \\
\text { Benefit Formula }\end{array}$ & $\begin{array}{c}\text { Limitation in } \\
\text { Benefit Change } \\
\text { From Pension } \\
\text { Value }\end{array}$ \\
\hline \hline $\begin{array}{l}\text { HRS cohort in } \\
1992\end{array}$ & $\begin{array}{c}76,828 \\
(1105)\end{array}$ & 72,619 & 66,695 & 4,209 & 10,133 \\
\hline $\begin{array}{l}\text { Early Boomers in } \\
2004\end{array}$ & $\begin{array}{c}81,692 \\
(266)\end{array}$ & 76,892 & 69,216 & 4,800 & 12,476 \\
\hline
\end{tabular}


While pensions mitigate the effect of the WEP adjustment to Social Security benefits, pensions from uncovered employment are part and parcel of the GPO adjustment, mechanically reducing spouse and survivor benefits of those with a public pension by two thirds of the value of that pension. Thus on the one hand, consideration of public pensions significantly reduces the downward adjustment to Social Security benefits due to WEP for those who worked in uncovered employment; on the other hand, consideration of pensions from uncovered employment is the sole determinant of the downward adjustment in spouse and survivor benefits from GPO.

\section{Conclusions}

This paper has investigated the effects of Social Security's Windfall Elimination Provision (WEP) and Government Pension Offset (GPO) provision on Social Security benefits received by individuals and households. A number of the innovations in this study turn out to be of central importance to having a full understanding of the effects of WEP and GPO adjustments. Unlike previous studies, we take explicit account of pensions earned on jobs not covered by Social Security, a key determinant of the size of WEP and GPO adjustments. Also unlike previous studies, we focus on the household. This allows us to incorporate the full effects of WEP and GPO on spouse and survivor benefits, and to evaluate the effects of WEP and GPO on the preretirement assets accumulated by affected families.

Our analysis is based on data from the original cohort of the Health and Retirement Study (HRS) and the most recent cohort for which a full set of required information is available. We constructed households from HRS data, estimated the paths of covered and uncovered employment and earnings for each spouse over their lifetimes, estimated the values

of pensions from uncovered work, calculated Social Security benefits using the Social Security Administration's ANYPIA program, and calculated the sizes of any WEP and GPO offsets. We also estimated the relations between the sizes of these adjustments and pension and other wealth accumulated by retirement age.

Among our specific findings are the following:

- $\quad$ Of 7,623 households in the original HRS cohort, 3.8 percent are subject to either WEP or to GPO. The comparable figure for the Early Boomer cohort is 3.5 percent. 
- $\quad$ Among the HRS households affected by either WEP or GPO, the WEP adjustment is $\$ 17,050$ and the GPO adjustment is another $\$ 14,101$, reducing the present value of Social Security benefits by 24.1 percent among the affected households. For the Early Boomer cohort, WEP and GPO reduce the present value of Social Security benefits by 18.5 percent.

- $\quad$ For members of the original HRS cohort affected by WEP or GPO, benefits lost amount to ten percent of the value of pensions plus Social Security they in fact receive and to 6.1 percent of their total wealth. Comparable losses for members of the Early Boomer cohort amount to 8.7 percent of total Social Security plus pension wealth and 5.3 percent of total wealth.

- $\quad$ By far the largest impact is on households affected by both WEP and GPO. Those from the original HRS cohort lose $\$ 45,786$ in present value of benefits, or 38.9 percent of their total Social Security benefits. Those subject to WEP and GPO from the Early Boomer cohort lose 28.7 percent of their benefit.

- We also decomposed the effects of the WEP adjustment into two parts, the part due to the use of a lower replacement rate up to the first bend point in the PIA formula, and the mitigation of this adjustment by the pension. Limiting the reduction in the Social Security benefit to half the size of the pension from uncovered employment reduces the penalty from WEP for members of the original HRS cohort by $\$ 5,924$, that is, by 58 percent. For the Early Boomers, the reduction in the replacement rate alone would lower benefits by $\$ 12,476$, so limiting the adjustment to half the value of the pension from uncovered work reduces the WEP penalty by $\$ 7,676$, or by 61.5 percent.

We have also discussed the rationale for the specification of WEP and GPO adjustments to Social Security benefits under current law. This law is designed to address a number of perceived inequities when those who work on jobs not covered by Social Security also become eligible for own, or for spouse or survivor benefits under Social Security.

The law does meet a number of its purposes. However, the limitation of the WEP offset to half the value of the pension mitigates the effects of this adjustment. The clear winners in this system are the individuals who benefit from the progressive Social Security benefit formula, having worked in both covered and uncovered employment, having become entitled to a Social Security benefit, but who had little or no pension from uncovered work. These 
individuals experience only modest effects of WEP and GPO adjustments. Consequently, they have gained a higher rate of return to Social Security taxes paid than those who continuously work in covered jobs. The reason is that work in uncovered employment is counted as zero years of earnings.

It has been argued that the WEP adjustment disproportionately affects low wage workers because it is applied only up to the first bend point of average indexed earnings. However, this argument ignores the effect of limiting WEP adjustments to half the value of the pension earned on the uncovered job. Social Security benefits will only be affected if the individual has high enough earnings in government or other uncovered employment to generate a large pension. Consequently, those who criticize the design of WEP and GPO on distributional grounds are exaggerating their case. This is not to say, however, that there is no case for redesign.

In addition, the law does not address all potential inequities. The Government Pension Offset adjustment seems fair when comparing two earner households with identical earnings histories. In one, both spouses always worked in covered employment and paid payroll taxes. In the other, the lower paid spouse did not work in covered employment and thus did not pay taxes. In the absence of the GPO, the household where the low earner worked in uncovered government employment would not have the top up to spouse benefits reduced by own Social Security benefits, as is standard for dual beneficiaries. That household would therefore receive higher spouse and survivor benefits than the household where work was exclusively in covered employment. On the other hand, GPO seems to be quite unfair to affected households when they are compared to one earner households, where one spouse receives the full spouse or survivor benefits. Here we have two households, where the primary earner paid Social Security taxes in both, while the spouse did not. Yet one will receive full spouse and survivor benefits, while the other will have spouse and survivor benefits reduced or eliminated. At the heart of this problem is the disparate treatment favoring one earner over two earner households, whether the low earner of the two earner household worked in uncovered employment, or only in covered employment. ${ }^{15}$

\footnotetext{
${ }^{15}$ For studies of the effects of spouse and survivor benefits on redistribution fostered by the Social Security benefit formula, see Gustman and Steinmeier (2001) and Gustman, Steinmeier and Tabatabai (2013).
} 
We conclude by reminding the reader of a number of caveats affecting our estimates of WEP and GPO adjustments. First, respondents underreport the extent they work for a government employer. To partially deal with this underreporting, we counted a respondent as working for a government if there is a self-report of having worked for a federal, state or local government employer, or if the respondent reported working in an uncovered job. But not all jobs that are not covered by Social Security are government jobs. Second, there are small inconsistencies in the Social Security records that we use to identify covered and uncovered employment. Third, throughout the analysis, we calculate WEP and GPO adjustments using respondent self-reports about expected pension values, which we link to uncovered employment. GAO (2007) indicates that government pension income is not always accurately reported to the Social Security Administration by affected workers. To the extent that government pensions are underreported to SSA, we overstate the size of WEP and GPO adjustments. Fourth and last, we remind the reader of a caveat we noted at the outset. We have not included behavioral responses to WEP and GPO as affected respondents and members of their households react to the incentives created by these policies. It is, of course, unclear how many understand these incentives and make their employment and benefit election choices with these incentives in mind. 


\section{References:}

Brown, Jeffrey R. and Scott Weisbenner. 2012. "The Distributional Effects of the Social Security Windfall Elimination Provision”. NBER Working Paper 18342.

Compson, Michael C. 2011. “The 2006 Earnings Public Use Micro Data File”. Social Security Bulletin 71(4).

Congressional Research Service. 2013a. “Social Security: The Windfall Elimination Provision (WEP)”. Christine Scott.

Congressional Research Service. 2013b. "Social Security: The Government Offset Provision (GPO)”. Christine Scott.

Diamond, Peter A. and Peter R. Orszag. 2003. "Reforming the GPO and WEP In Social Security”. Tax Notes, November 3: 647-649.

General Accounting Office. 2007. "Issues Regarding the Coverage of State and Local Government Employees.” Statement of Barbara D. Bovbjerg Before the Committee on Social Security, Pensions and Family Policy, Committee on Finance, U.S. Senate.

General Accounting Office. 2010. “Management Oversight Needed to Ensure Accurate Treatment of State and Local Government Employees”. GAO-10-938.

Gustman, Alan L. and Thomas L. Steinmeier. 1999. “Effects of Pensions on Savings: Analysis with Data From the Health and Retirement Study.” Carnegie-Rochester Conference Series 50: 271-326. 2000. "Social Security Benefits of Immigrants and U.S.

Born. In George Borjas, editor, Issues in The Economics Immigration. Chicago: University of Chicago Press: 309-350. 2001. "How Effective Is Redistribution Under The Social

Security Benefit Formula?”. Journal of Public Economics 82(1): 1-28.

Gustman, Alan L., Thomas L. Steinmeier and Nahid Tabatabai. 2013. "Redistribution Under the Social Security Benefit Formula at the Individual and Household Levels, 1992 and 2004. Journal of Pension Economics and Finance 12(1), January, 2013: 1-27.

Social Security Administration. 2012a. “Windfall Elimination Provision”. SSA Publication No. 05-10045 ICN 460275. June.

Social Security Administration. 2012b. “Government Pension Offset”. SSA Publication No. 05-10007 ICN 451453. June. 